\title{
Main progress and problems in research on Ordovician hydrocarbon accumulation in the Tarim Basin
}

\author{
Pang Xiongqi ${ }^{1,2 *}$, Tian Jun ${ }^{3}$, Pang Hong ${ }^{1,2}$, Xiang Caifu ${ }^{1,2}$, Jiang Zhenxue ${ }^{1,2}$ \\ and Li Sumei ${ }^{1,2}$ \\ ${ }^{1}$ Basin and Reservoir Research Center, School of Natural Resources and Information Technology, China University of \\ Petroleum, Beijing 102249, China \\ ${ }^{2}$ State Key Laboratory of Petroleum Resources and Prospecting, China University of Petroleum, Beijing 102249, China \\ ${ }^{3}$ PetroChina Tarim Oilfield Company, Korla, Xinjiang 841000, China
}

(C) China University of Petroleum (Beijing) and Springer-Verlag Berlin Heidelberg 2010

\begin{abstract}
The Tarim Basin is the largest petroliferous basin in the northwest of China, and is composed of a Paleozoic marine craton basin and a Meso-Cenozoic continental foreland basin. It is of great significance in exploration of Ordovician. In over 50 years of exploration, oil and gas totaling over 1.6 billion tonnes oil-equivalent has been discovered in the Ordovician carbonate formation. The accumulation mechanisms and distribution rules are quite complicated because of the burial depth more than 3,500 m, multi-source, and multi-stage accumulation, adjustment, reconstruction and re-enrichment in Ordovician. In this paper, we summarized four major advances in the hydrocarbon accumulation mechanisms of Ordovician carbonate reservoirs. First, oil came from Cambrian and Ordovician source rocks separately and as a mixture, while natural gas was mainly cracked gas generated from the Cambrian-Lower Ordovician crude oil. Second, most hydrocarbon migrated along unconformities and faults, with different directions in different regions. Third, hydrocarbon migration and accumulation had four periods: Caledonian, early Hercynian, late Hercynian and Himalayan, and the latter two were the most important for oil and gas exploration. Fourth, hydrocarbon accumulation and evolution can be generally divided into four stages: Caledonian (the period of hydrocarbon accumulation), early Hercynian (the period of destruction), late Hercynian (the period of hydrocarbon reconstruction and re-accumulation), and Himalayan (the period of hydrocarbon adjustment and re-accumulation). Source rocks $(\mathrm{S})$, combinations of reservoir-seal (C), paleo-uplifts $(\mathrm{M})$, structure balance belt (B) matched in the same time $(\mathrm{T})$ control the hydrocarbon accumulation and distribution in the Ordovician formations. Reservoir adjustment and reconstruction can be classified into two modes of physical adjustment and variation of chemical compositions and five mechanisms. These mechanisms are occurrence displacement, biodegradation, multi-source mixing, high-temperature cracking and late gas invasion. Late hydrocarbon accumulation effects controlled the distribution of current hydrocarbon. The T-BCMS model is a basic geological model to help understanding the control of reservoirs. At present, the main problems of hydrocarbon accumulation focus on two aspects, dynamic mechanisms of hydrocarbon accumulation and the quantitative models of oil-bearing in traps, which need further systemic research.
\end{abstract}

Key words: Tarim Basin, carbonate reservoirs, oil and gas exploration of the Ordovician, hydrocarbon accumulation mechanism, hydrocarbon enrichment rule

\section{Introduction}

The Tarim Basin is located in the northwest of China with an area of $56 \times 10^{4} \mathrm{~km}^{2}$, and has abundant oil and gas resources. The basin is mainly composed of Sinian-Permian

*Corresponding author. email: pangxq@cup.edu.cn

Received September 2, 2009 marine basin and Meso-Cenozoic non-marine basin. After more than 50 years of exploration, the total oil and gas which has been discovered in Ordovician carbonate reservoirs is over 1.6 billion tonnes oil-equivalent, and the Ordovician has become one of the key hydrocarbon-bearing systems in the platform-basin. The Ordovician in the Tarim Basin is marine carbonate, in which oil and gas reservoirs have complicated geological characteristics, diverse types and complex hydrocarbon properties (Kang, 1999; Zhou et al, 2000; Liu et 
al, 2004; Lü et al, 2004; Yang et al, 2007a). The Ordovician is also one of the most important hydrocarbon source rocks of reservoirs already found. Moderate-mature platform margin lime-mud source rocks and black shale source rocks were developed in the upper-middle Ordovician (Liang et al, 2000; Shou et al, 2009). In addition, the Ordovician is the most problematic system in current exploration, and considerable controversies still exist about reservoir-forming mechanisms and accumulation rules (Liang et al, 2000; Zhang, 2001; Zhao et al, 2001; Zhao and Li, 2002; Cai et al, 2007; Li et al, 2008; Lü et al, 2007). The Ordovician carbonate in the Tarim Basin has complex reservoir conditions and great exploration potential, so research on the mechanisms of Ordovician hydrocarbon accumulation is of great practical significance in advancing oil and gas exploration and alleviating the problem of oil and gas shortages in China.

\section{Distribution characteristics of Ordovician reservoirs and discovery process}

Starting in 1988, the Ordovician oil and gas exploration has discovered six oil and gas fields: Lunnan, Yingmai202 and Tahe oilfields, and Lungudong, Tazhong1 and Hetianhe gas fields (Fig. 1), totaling 1.6 billion tonnes and averaging 260 million tonnes oil equivalent.

The largest field is the Tahe oilfield, with reserves of 617 million tonnes and the smallest field is Yingmai202 oilfield, with the reserves of 31 million tonnes. The reserves of these oil and gas fields are shown in Fig. 2.

The Ordovician reservoirs are mainly distributed in three

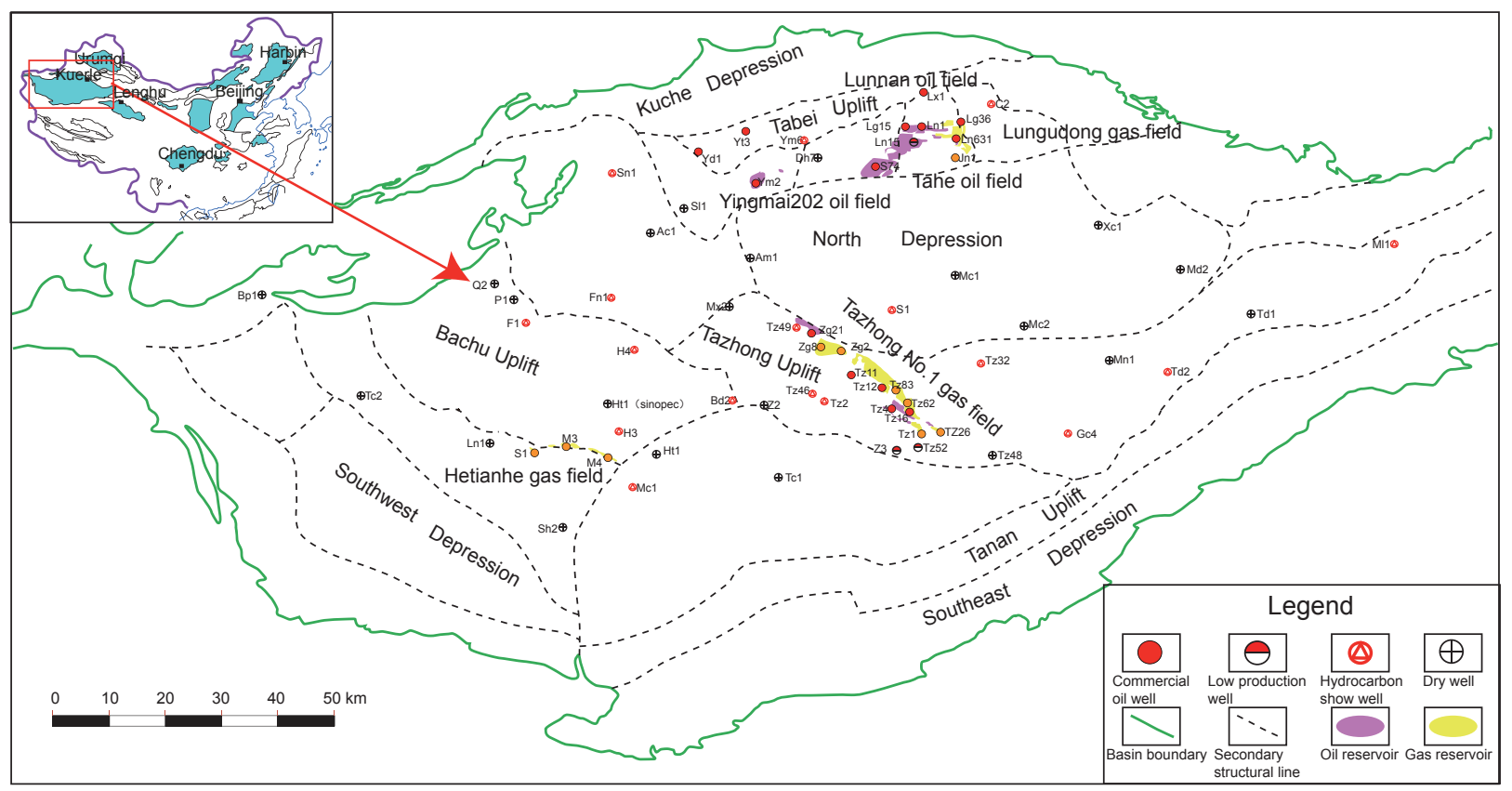

Fig. 1 Distribution of Ordovician hydrocarbon reservoirs in the Tarim Basin

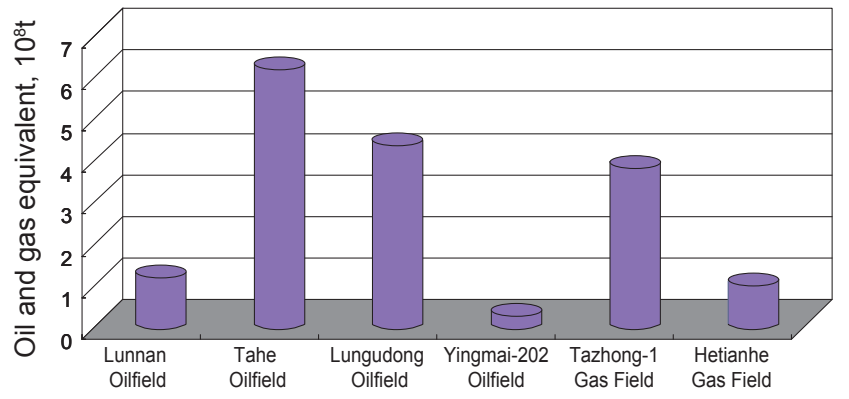

Fig. 2 Reserves of Ordovician oil and gas fields in the Tarim Basin

paleo-uplifts: the Tabei, Tazhong and Bachu uplifts (Fig. 1). The largest reservoir, with the reserves of 1.12 billion tonnes, has been found in the Tabei uplift, and the hydrocarbon distribution characteristic is gas in the east and oil in the west. The second largest reservoir, with the reserves of $3.8 \times 10^{8}$ t, has been found in the Tazhong uplift, and the hydrocarbon distribution characteristic is gas in the north and oil in the south. The smallest reservoir, with the reserves of 90 million tonnes, has been found in the Bachu uplift.

Stratigraphically the Ordovician reservoirs are mainly distributed in four target layers (Fig. 3(a)). They are the Yingshan, Lianglitage, Yijianfang, and Penglaiba Formations, the oil and gas reserves of which decrease one by one from one billion tonnes to one million tonnes. The Yingshan Formation hydrocarbon is distributed in the Tazhong, Tabei, and Bachu areas, with oil reservoirs mainly in the western regions of Tabei, while condensate gas reservoirs in the Bachu, Tazhong and eastern Tabei areas. The Yijianfang Formation hydrocarbon, dominated by condensate gas, is mainly distributed in the Lungudong area. The Lianglitage Formation hydrocarbon is mainly distributed in the Lungudong and Tazhong areas, with condensate gas reservoirs in the Lungudong area and outside the Tazhong 
No.1 slope break zone, and oil reservoirs inside the slope break zone. Hydrocarbon is rarely found in the Penglaiba Formation, and only condensate gas was found in the TZ162 well.

The Ordovician reservoirs are mainly distributed at depths of 3,500-7,000 m (Fig. 3(b)) about $200 \mathrm{~m}$ below the regional cap rocks and locally more than $300 \mathrm{~m}$. They were mainly discovered from 1988 to 2008 (Fig. 4). In 1988, hydrocarbon was firstly discovered in the Ordovician of Lunnan-1 well and a commercial oil flow of $14.47 \mathrm{~m}^{3}$ per day was obtained with a $9.525 \mathrm{~mm}$ choke. After acidification, heavy oil was produced at a rate of $97.46 \mathrm{~m}^{3}$ per day. The years from 1989 to 1996 was a lean time for Ordovician exploration. Only about 10 wells with commercial oil flow were found out of a total of 80 wells. The oil and gas shows were generally found in Ordovician weathering crust, and then the belief of large areas of Ordovician bearing oil was established, which laid the foundation for future Ordovician exploration. From 1997 to 2008 , with the progress of geological understanding and using new exploration technologies, the Ordovician oil and gas production in the Tarim Basin had increased year after year. Since $2002,71 \%$ of newly-added geological reserves in Tarim oilfields have been discovered in the Ordovician carbonate reservoirs.

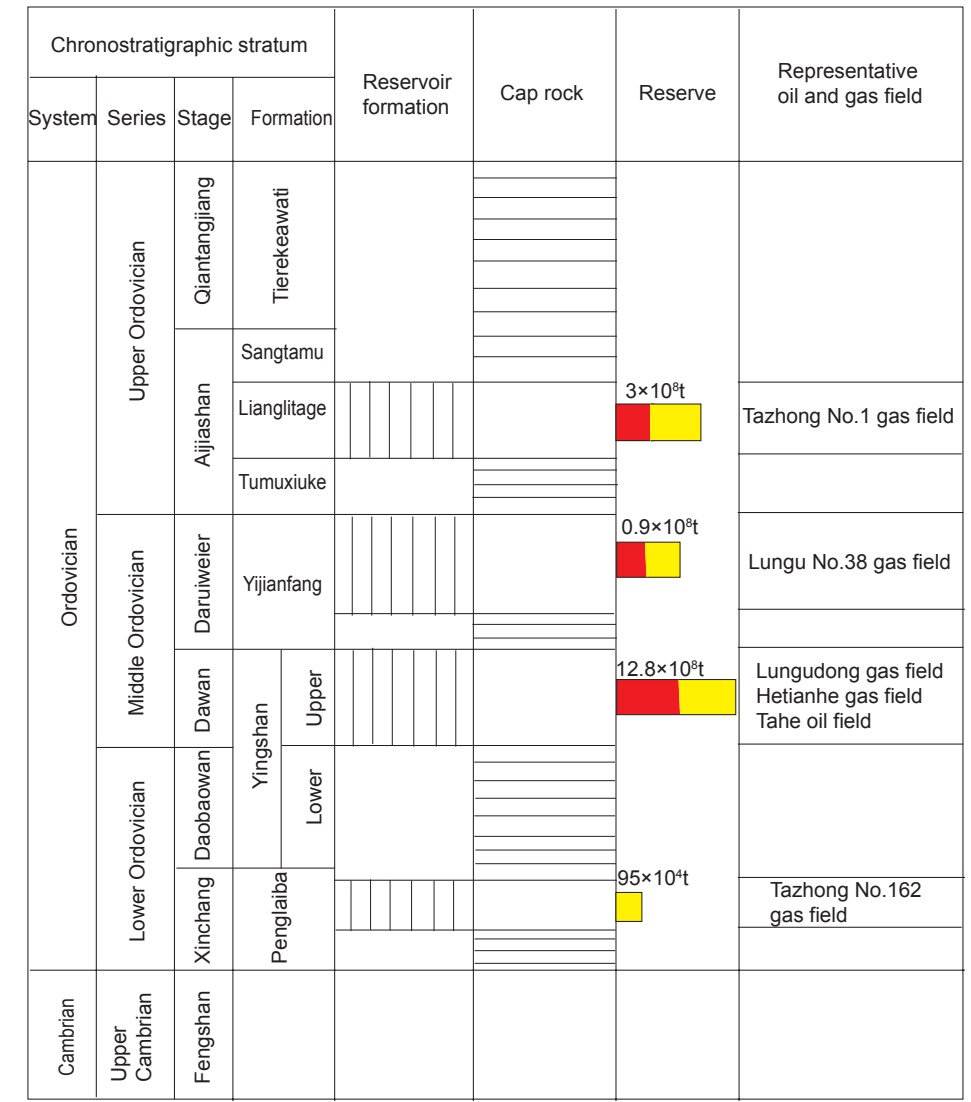

(a) Ordovician strata division of the Tarim Basin

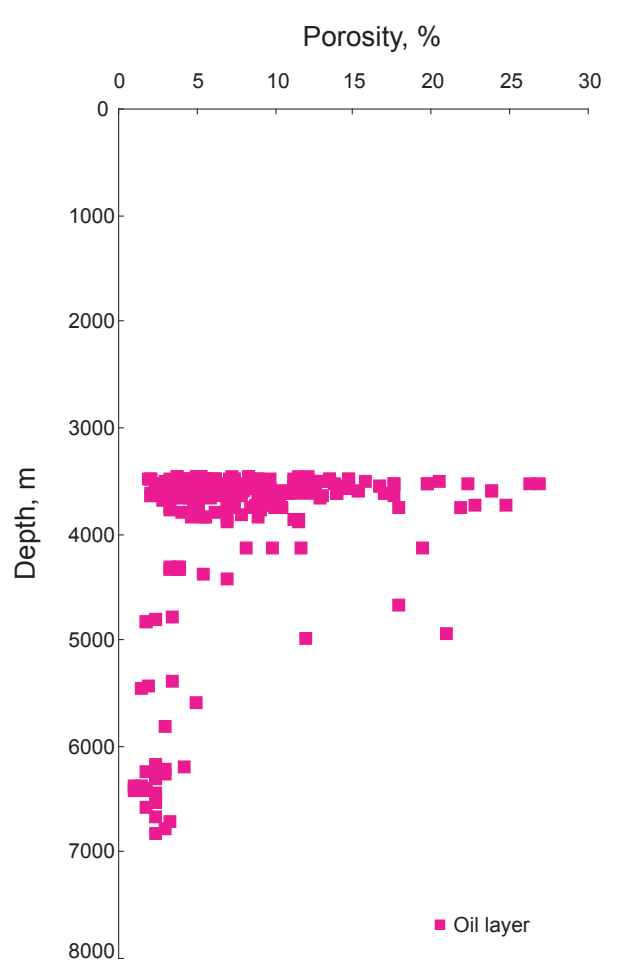

(b) Depth distribution of Ordovician reservoirs in the Tarim Basin

Fig. 3 Vertical distribution of Ordovician reservoirs in the Tarim Basin

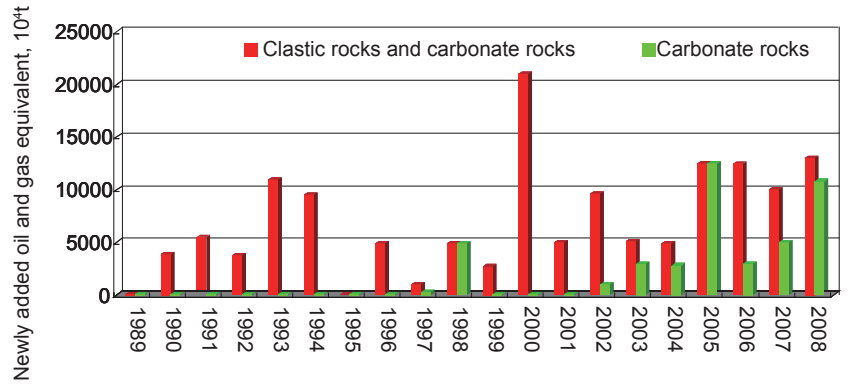

Fig. 4 Annual newly increased proven reserves of Ordovician carbonate reservoirs in the Tarim Basin

\section{Geological characteristics of Ordovician carbonate reservoirs}

\subsection{High-quality reef-bank facies reservoirs are controlled by the conditions of lithofacies palaeogeography}

The Ordovician reef-bank facies reservoirs in the Tarim Basin are mainly distributed along the edge of the platform, which is the potential sedimentary facies zone for the development of high quality reservoirs.

1) The characteristics of reef-bank facies reservoirs. The Ordovician Yingshan and Penglaiba formations have similar sedimentary characteristics (Fig. 5(a) and 5(b)), 
both developed carbonate platforms, Lundong-Gucheng and Luoxi platform margin facies, with a width of 5-20 km and an area of $4,000 \mathrm{~km}^{2}$. The Yijianfang Formation deposition is not found in the Tazhong and Bachu areas, and three platform margins developed: south of Tabei, lower wall of the Tazhong No.1 slope break zone and north of the Tangguzibasi Depression (Fig. 5(c)), with an exploration area of 5,000 km². For the Lianglitage Formation deposition, three carbonate platforms and four platform margins were developed, covering an exploration area of $15,800 \mathrm{~km}^{2}$, including the Tazhong No.1, Lungudong and Ma401 gas fields.

2) The physical properties of reef-bank facies reservoirs. The reef-bank facies reservoirs, with the characteristics of superimposition, have a general porosity between 3\%-6\%, permeability of 0.1-10 md, single layer thickness of $1-5 \mathrm{~m}$ and total thickness of 30-90 m.
3) The controlling factors of reef-bank facies highquality reservoirs. The high energy reef-bank sedimentary facies controlled the lithology and structure of the rock, and further controlled the development of primary porosity. Early exposed cellular erosion (or syngenetic exposed erosion) served as a key factor in forming high-quality cavity layers. Tectonism played an important role in improving the properties of reef reservoirs, especially the activities of the late strike-slip faults. The faults and fracture systems not only provided communicate between cavity layers and laid the foundation for high and stable production, but also provided favorable oil and gas migration pathways to form reservoirs.

\subsection{Complicated hydrocarbon properties, showing various colors}

In the Tarim Basin, even in a single Ordovician

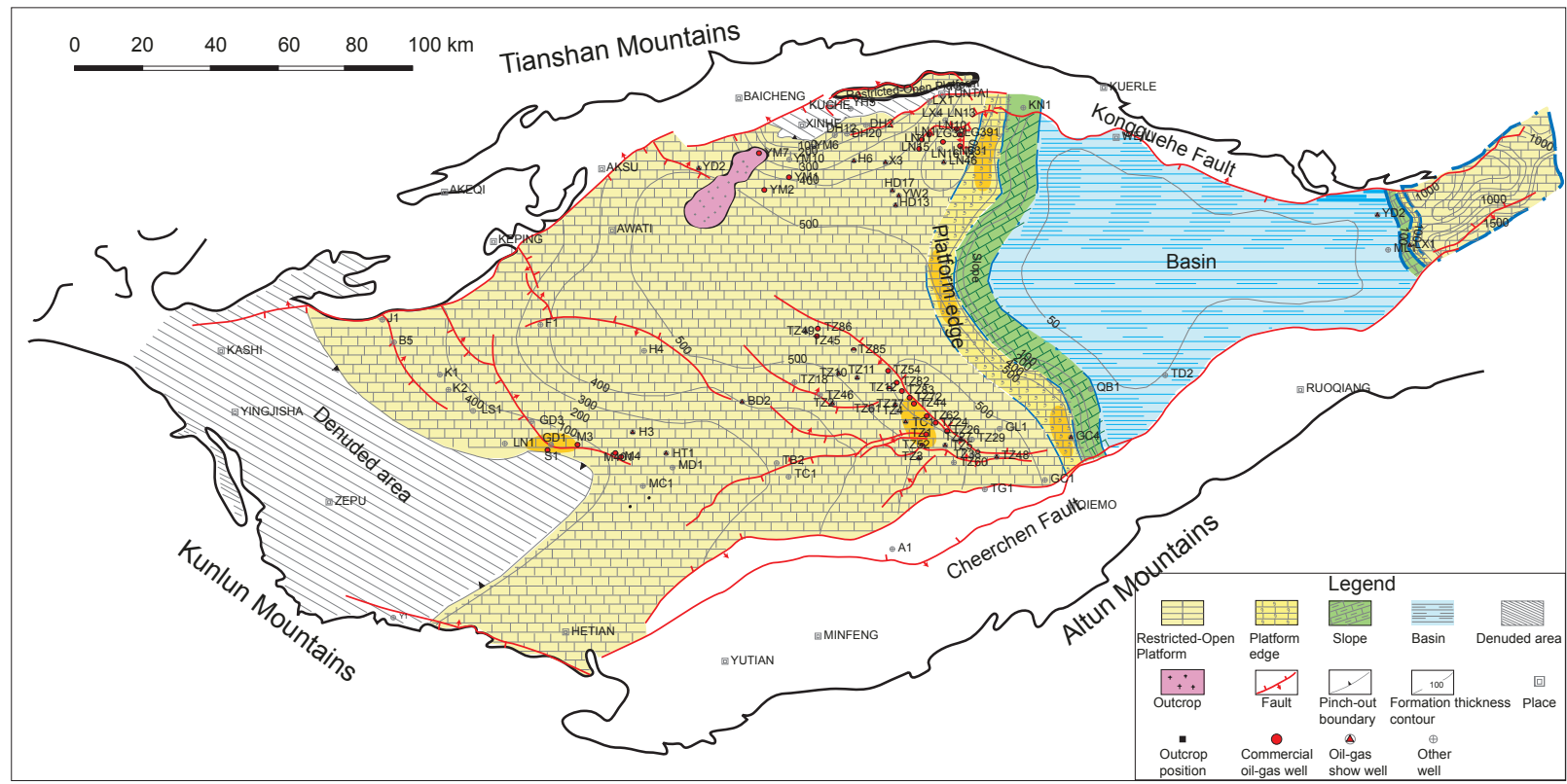

(a) Sedimentary facies of the lower Ordovician Penglaiba Formation in the Tarim Basin

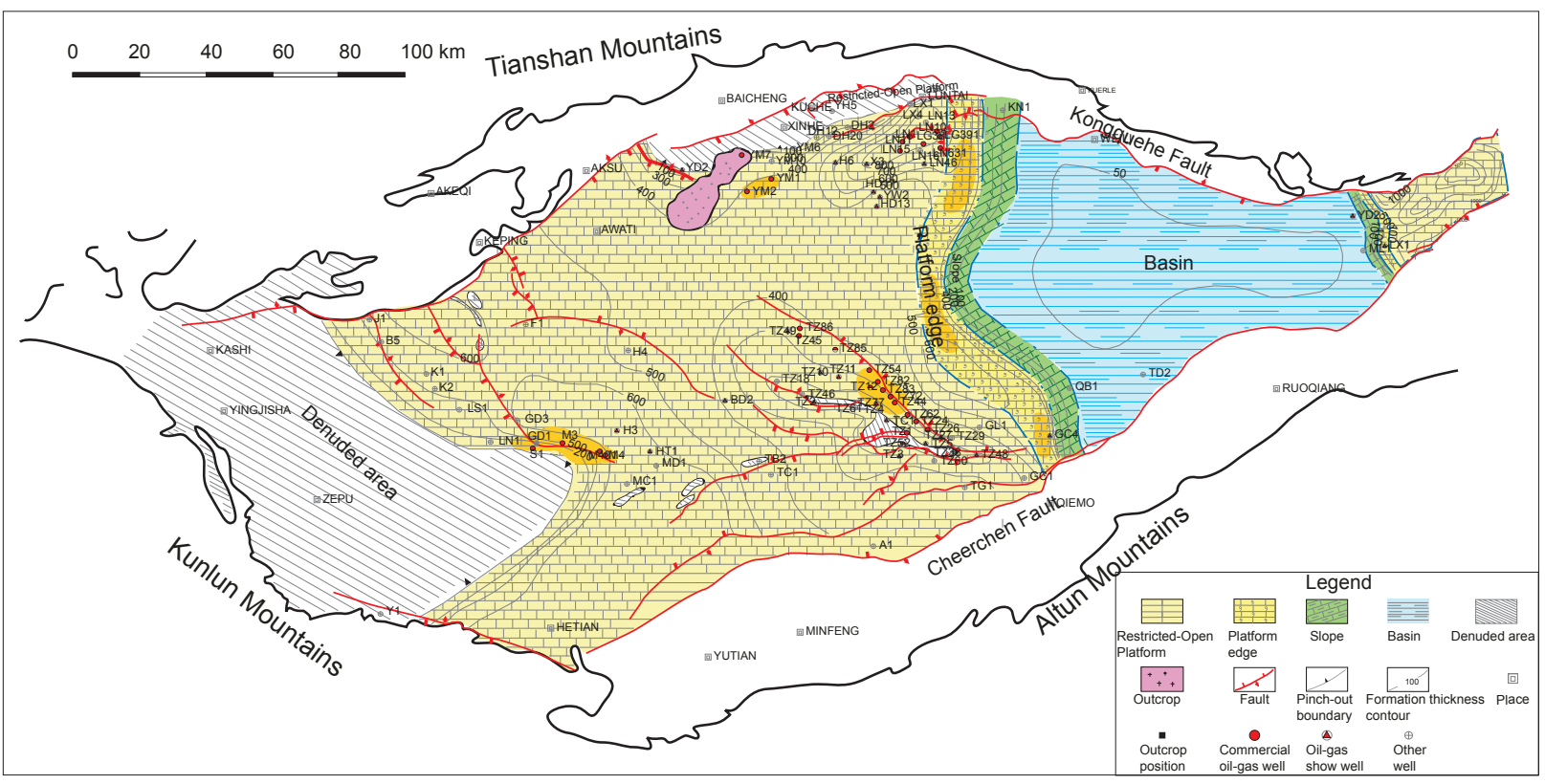

(b) Sedimentary facies of the lower Ordovician Yingshan Formation in the Tarim Basin 


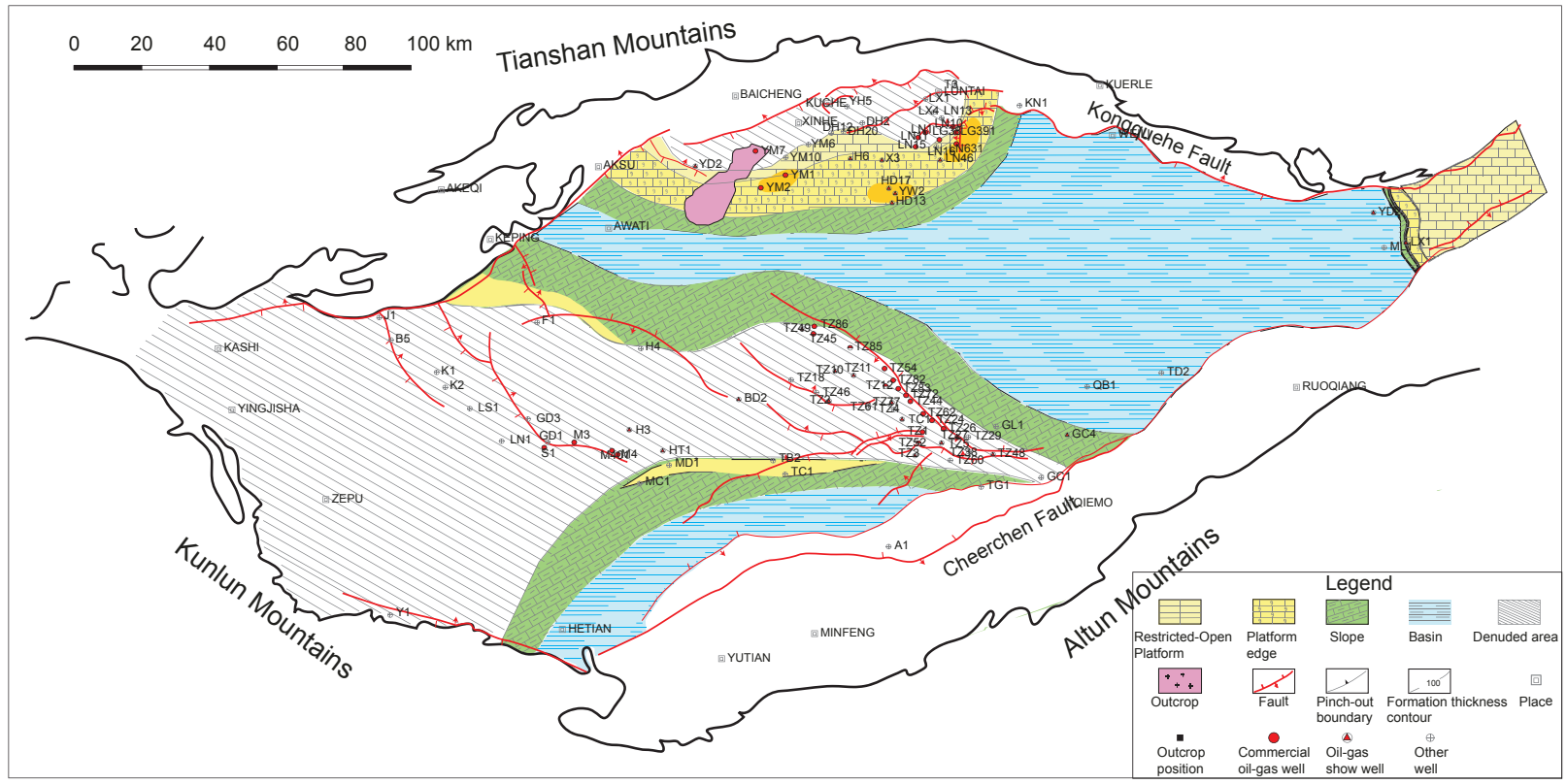

(c) Sedimentary facies of the middle Ordovician Yijianfang Formation in the Tarim Basin

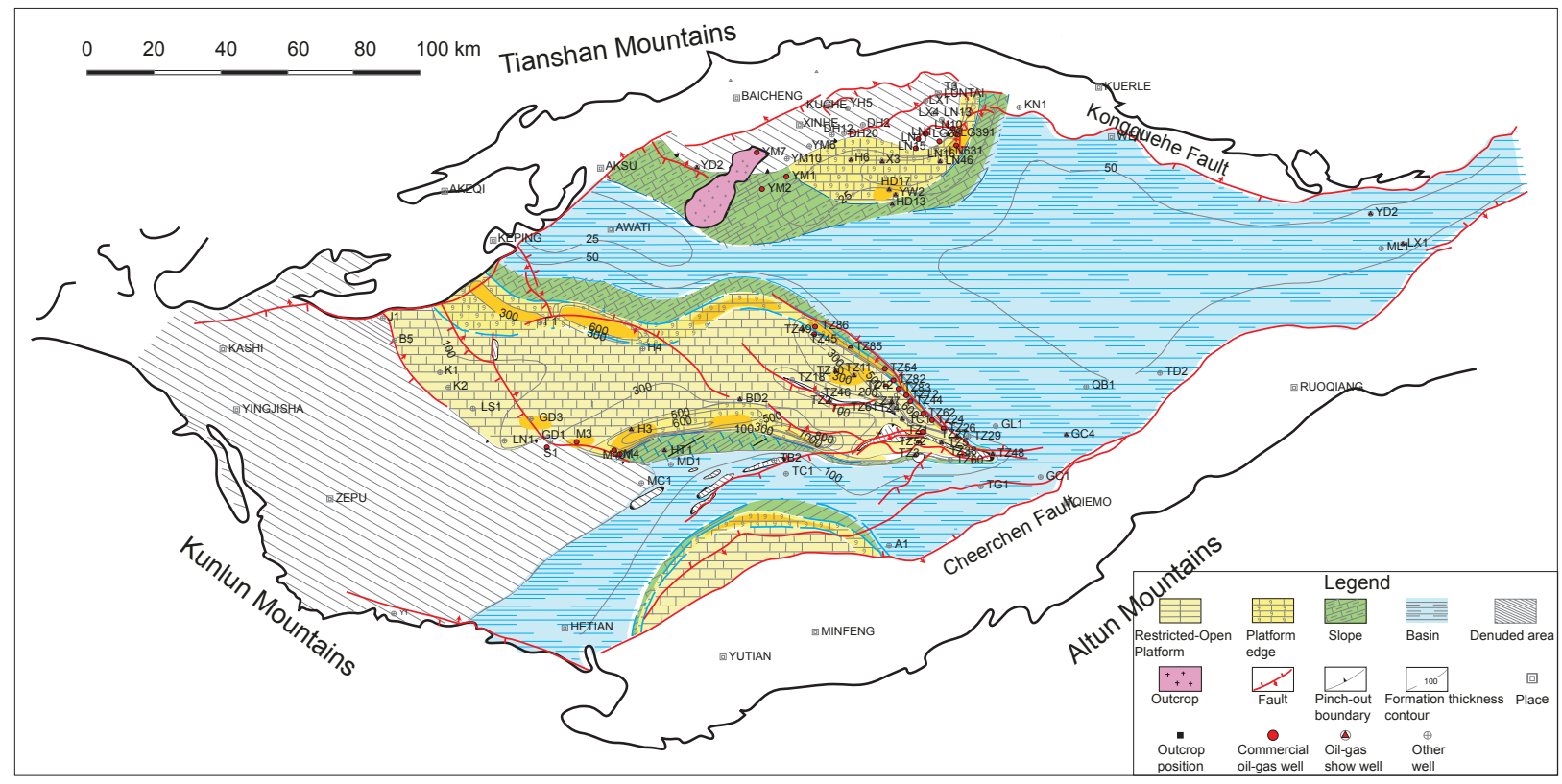

(d) Sedimentary facies of the upper Ordovician Lianglitage Formation in the Tarim Basin

Fig. 5 Sedimentary facies of each Ordovician formation in the Tarim Basin (Li et al, 2010a)

reservoir, a variety of oil types coexist, therefore hydrocarbon properties are complicated (Fig. 6). The Ordovician oilbearing reservoirs, have normal temperature and pressure systems and over 1,000 meters depth difference, and hydrocarbon distribution is not controlled by the local high points. In section, the Ordovician reservoirs have quasilayered distribution, and do not have uniform oil-gas-water interfaces. Alternating high production wells, stripped wells and dry wells demonstrate complicated rules. In addition, the petroleum occurs as different types, including black oil, condensate oil, weak volatile oil, heavy oil, asphalt, and natural gas.

\section{Major advances and problems in research of Ordovician hydrocarbon accumulation mechanisms}

The oil and gas fields in the Ordovician formation of the Tarim Basin have been explored by PetroChina and Sinopec for nearly thirty years. In the process of exploration, a series of complicated geological problems still need to be resolved, including the following five aspects.

1) The hydrocarbon sources are unknown, i.e., which formations are the main sources providing the hydrocarbon for the Ordovician reservoirs. Some scholars think that the oil 


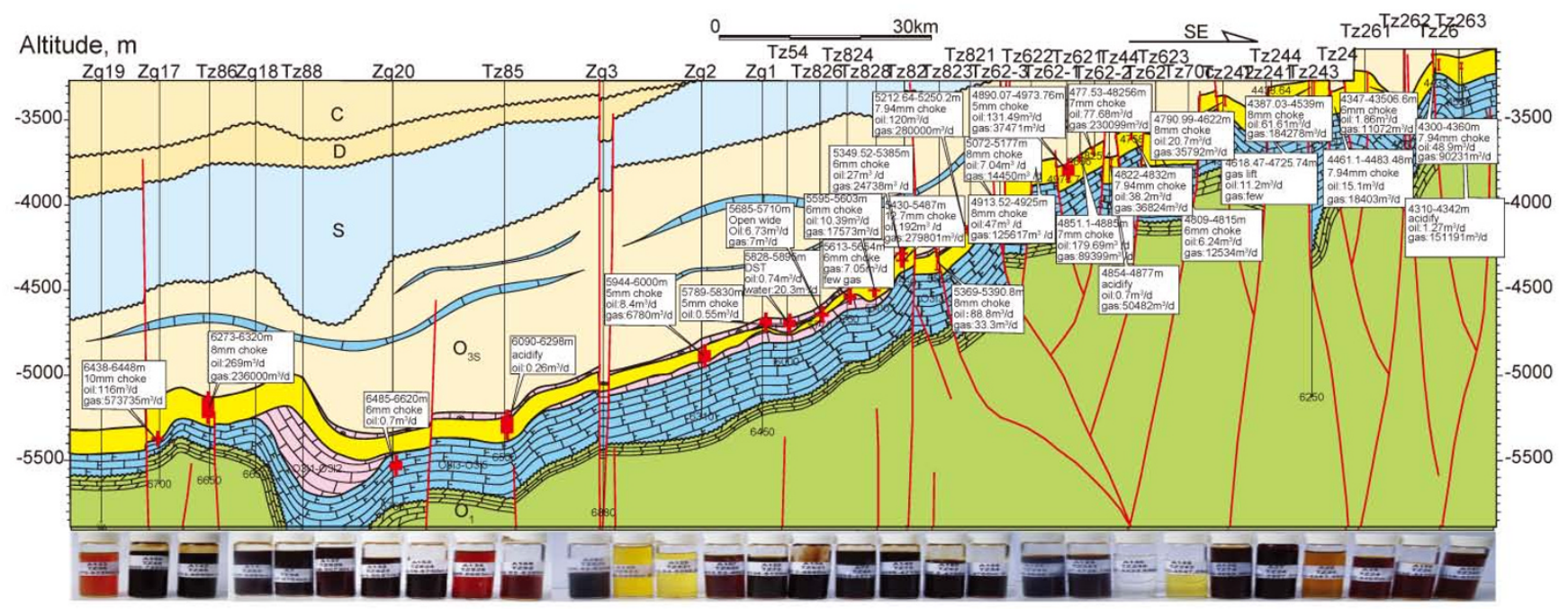

Fig. 6 Distribution of Ordovician hydrocarbon properties in the Tazhong area

and gas in Ordovician reservoirs are mainly from Ordovician source rocks, some think that they are mainly from Cambrian source rocks and some think that they are mixed oils from both Ordovician and Cambrian source rocks, but the contribution ratios of Ordovician and Cambrian sources are still unknown.

2) The hydrocarbon migration pathways are unknown, i.e., which is the main pathway for hydrocarbon migration. Some scholars think that unconformities are the main pathway for hydrocarbon migration, some think that karst caves and cracks are the main pathways, and other think that faults are the main pathways.

3) The amount of hydrocarbon accumulation is still unknown. Not only can the Ordovician source rocks supply the hydrocarbon to Ordovician formations, but also can the Cambrian source rocks. The Cambrian source rocks are very thick and their distribution is widespread, but the amount of hydrocarbon they can supply to Ordovician formations after long deep burial and evolution still needs considerable study. The Ordovician source rocks are thin, their distribution area is limited and their maturity is low in some areas, so how much hydrocarbon they can supply to Ordovician formations also needs to be studied.

4) The hydrocarbon accumulation periods are still unknown. There are many hydrocarbon accumulation periods for Ordovician reservoirs during geological history, but the exact time and periods of hydrocarbon accumulation are still not definite. The difference in hydrocarbon accumulation periods among different zones is the main problem to be defined.

5) The dynamic force driving hydrocarbon accumulation is still unknown.

In recent years, many Chinese scholars aimed at resolving the main problems in the hydrocarbon accumulation mechanisms and got a series of research results under the support of National 973 Project (Table 1). On basis

Table 1 Advances in understanding Ordovician hydrocarbon accumulation mechanisms in the Tarim Basin

\begin{tabular}{|c|c|c|c|}
\hline $\begin{array}{l}\text { Reservoir genetic } \\
\text { mechanism }\end{array}$ & Main viewpoint & $\begin{array}{l}\text { Research object / } \\
\text { Region }\end{array}$ & References \\
\hline \multirow{3}{*}{$\begin{array}{l}\text { Hydrocarbon } \\
\text { sources }\end{array}$} & \multirow[b]{2}{*}{ Crude oil } & $\begin{array}{l}\text { Tazhong, } \\
\text { Tabei }\end{array}$ & Zhao and Li, 2002; Han et al, 2009 \\
\hline & & $\begin{array}{l}\text { Tazhong, } \\
\text { Tabei }\end{array}$ & Liang et al, 2000 \\
\hline & Mainly from mixed $\in-\mathrm{O}_{1}$ and $\mathrm{O}_{2+3}$ & Tazhong & Li et al, 2008 \\
\hline Amount of hydrocarbon & Crude oil from $\in-\mathrm{O}_{1}$ accounting for $13 \%-91 \%$ & Tazhong & Li et al, 2008 \\
\hline \multirow{3}{*}{$\begin{array}{l}\text { Pathway of hydrocarbon } \\
\text { migration }\end{array}$} & $\begin{array}{l}\text { migrate along the unconformities and faults from north to south } \\
\text { and from south to north }\end{array}$ & Yaha-Yingmaili & Zhang et al, 2000 \\
\hline & $\begin{array}{l}\text { migrate along the unconformities and faults from northeast to } \\
\text { southwest and from northwest to southeast }\end{array}$ & Tazhong & Guo et al, 2008 \\
\hline & $\begin{array}{l}\text { migrate along the unconformities and faults from southwest to } \\
\text { northeast and from southeast to northwest }\end{array}$ & $\begin{array}{l}\text { Lunnan, } \\
\text { Tahe }\end{array}$ & Shao, 2005 \\
\hline \multirow{2}{*}{$\begin{array}{l}\text { Period of hydrocarbon } \\
\text { accumulation }\end{array}$} & Three periods: Caledonian, late Hercynian, Himalayan & Platform-basin & Zhao and Li, 2002; Yang et al, 2007b \\
\hline & $\begin{array}{l}\text { Four periods: Early Caledonian, late Caledonian, late Hercynian- } \\
\text { Indosinian, Yanshan-Himalayan }\end{array}$ & Platform-basin & Pang et al, 2006 \\
\hline
\end{tabular}


of previous work and our recent research progress, we summarized the advancements in the Ordovician hydrocarbon accumulation mechanisms.

\subsection{Advances in understanding hydrocarbon sources}

The Ordovician oil in the Tarim Basin mainly came from the Cambrian-Ordovician source rocks. The gas came mainly from Cambrian-lower Ordovician source rocks, which is dominated by oil cracking gas. Fig. 7 is the example, more details are in the related references ( $\mathrm{Li}$ et al, 2010b).

\subsection{Advances in understanding hydrocarbon volumes}

Based on a detailed study of oil and gas sources in the Tazhong area, a new geochemical identification standard was

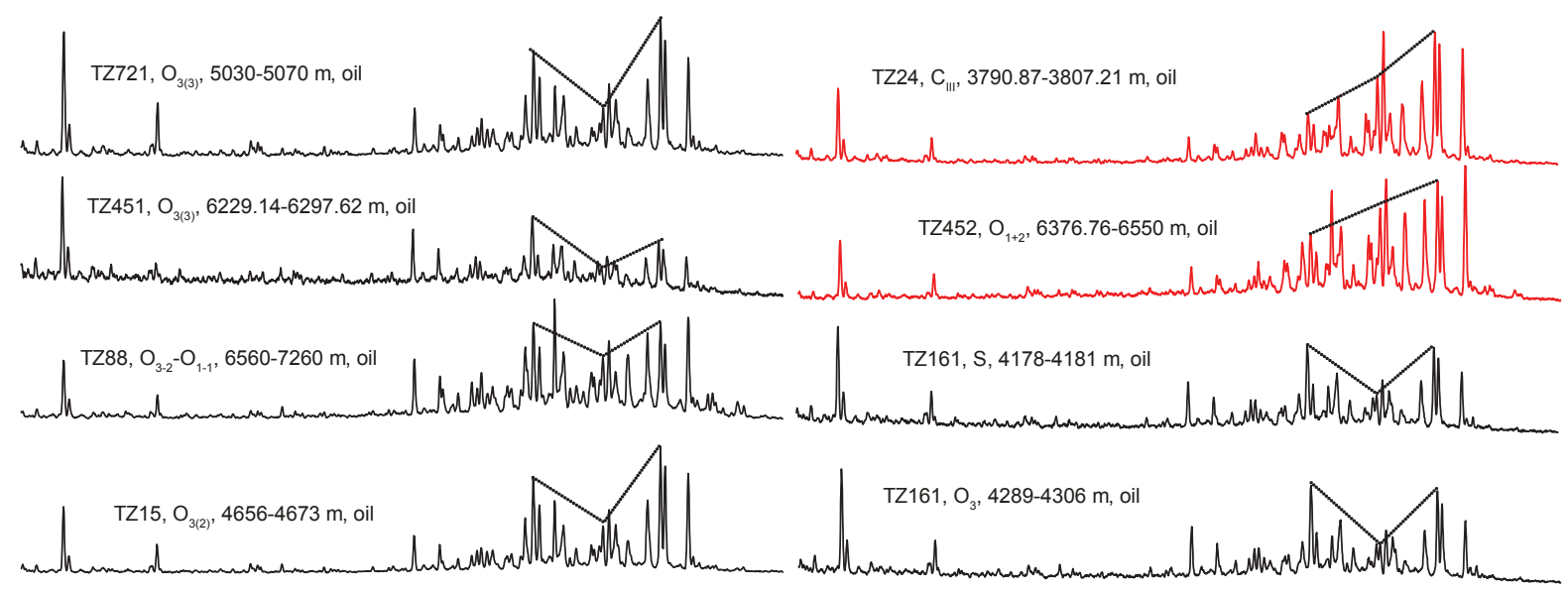

Source rock

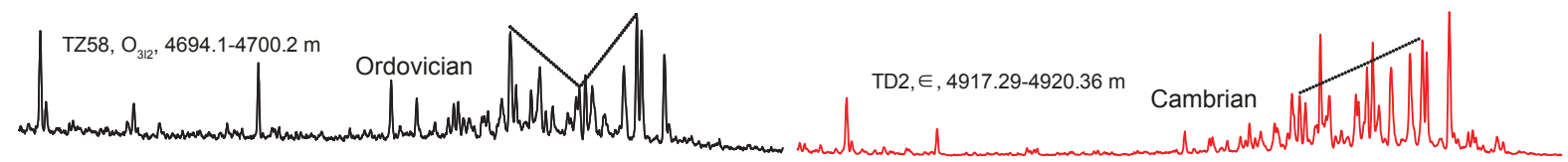

Fig. 7 Ordovician oil comes from both Cambrian and Ordovician sources

defined, and the oil-source correlation identification system was further improved. In addition, after comparing the differences in monomer hydrocarbon isotopic composition between the Cambrian-Lower Ordovician and the MiddleUpper Ordovician oil samples, the proportions of mixedsource hydrocarbon in the Tarim Basin were analyzed. The results indicated that the crude oil from the CambrianLower Ordovician accounted for $13 \%-91 \%$, and few were $100 \%$ residual oil reservoirs. The quantitative research of Ordovician oil sources in the Tabei uplift was done by this way, and the results showed that the relative contribution of Cambrian source decreased from east to west, with the proportion from $32 \%$ in the Lungudong area down to $28 \%$ in the Tahe area, and further down to $9 \%$ in the Halahatang area. The relative contribution of the Cambrian source increased with increasing the burial depth. Fig. 8 is the example of this advance.

\subsection{Advances in understanding hydrocarbon migration pathways}

The research on the carrier system is always weak, but actually it is an essential part in the research of hydrocarbon accumulation. In carbonate carrier systems, faults and unconformities are the most important migration channels, playing an important role in hydrocarbon migration and accumulation. The fault zones are not only the low fluid potential areas but also the favorable areas of hydrocarbon accumulation. Through a preliminary analysis, a conclusion was drawn that the hydrocarbon migrated from northeast to southwest and from northwest to southeast in the Tazhong area, from southwest to northeast and from southeast to northwest in the Lunnan area, from south to north or from north to south in the Yaha-Yingmaili area. Faulting is the most important controlling factor of hydrocarbon migration, which is mainly shown in the following four aspects: fault hydrocarbon transport; the fault intersection is the point of hydrocarbon charging; faulting can improve the reservoir properties around the fault during the formation of the fault, and the hydrocarbon productivity in the traps within $15 \mathrm{~km}$ of the fault is much higher than that in the traps far away; the fault blocking the trap can form the fault-block reservoirs. Fig. 9 shows the relationship between the distribution of hydrocarbon reservoirs and fault zones.

\subsection{Understanding of hydrocarbon accumulation periods}

There are four periods of hydrocarbon accumulation in Ordovician reservoirs, and the periods are different under different hydrocarbon accumulation conditions in different areas. The last hydrocarbon accumulation period is the most significant to the current oil and gas exploration because it experienced few late tectonic events after reservoir formation. The research into the carbonate reservoir accumulation periods is more difficult than that for clastic 

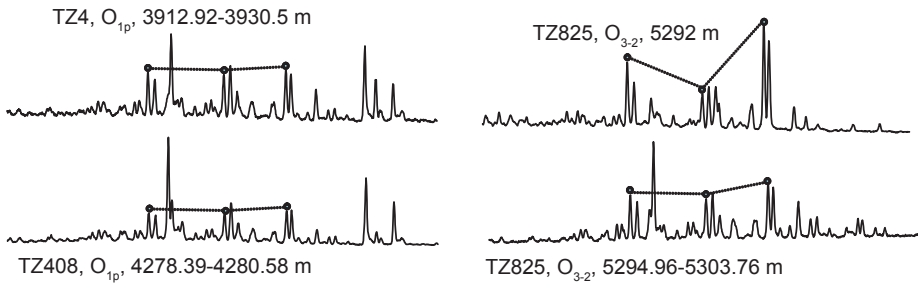

(a) The compositions in hydrocarbon inclusions show the mixed oil sources of Cambrian and Ordovician

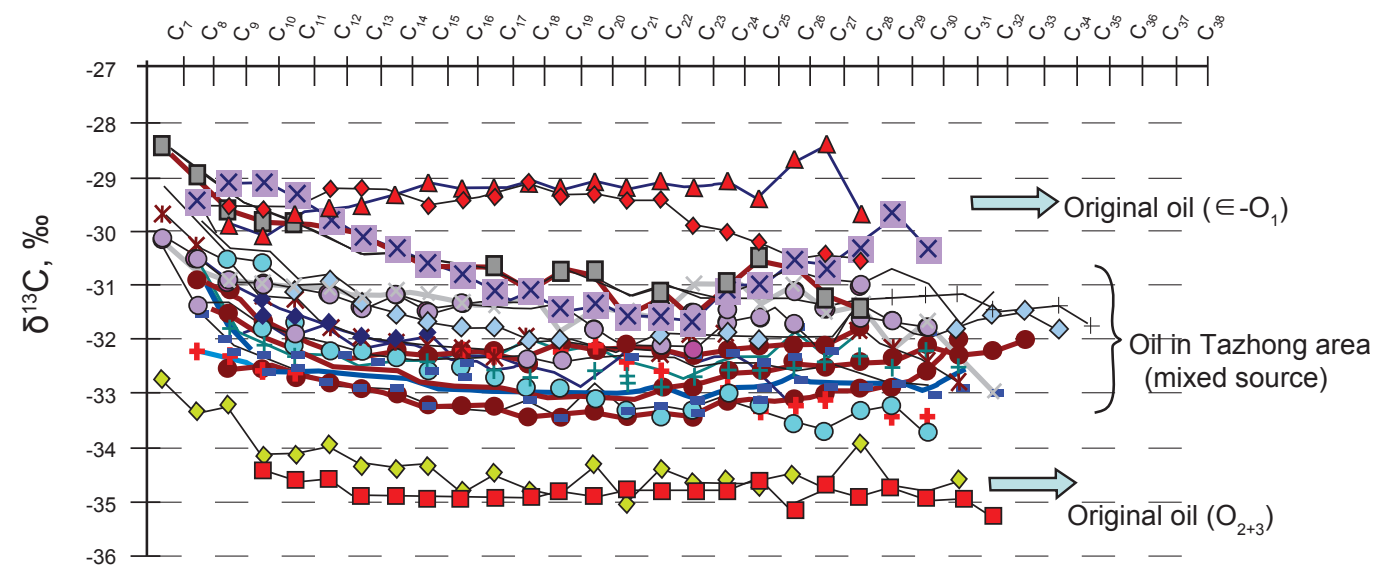

(b) The monomer hydrocarbon isotope shows how to identify the Cambrian source and Ordovician source

Fig. 8 Relative contribution of different sources can be identified by the monomer hydrocarbon isotope technology

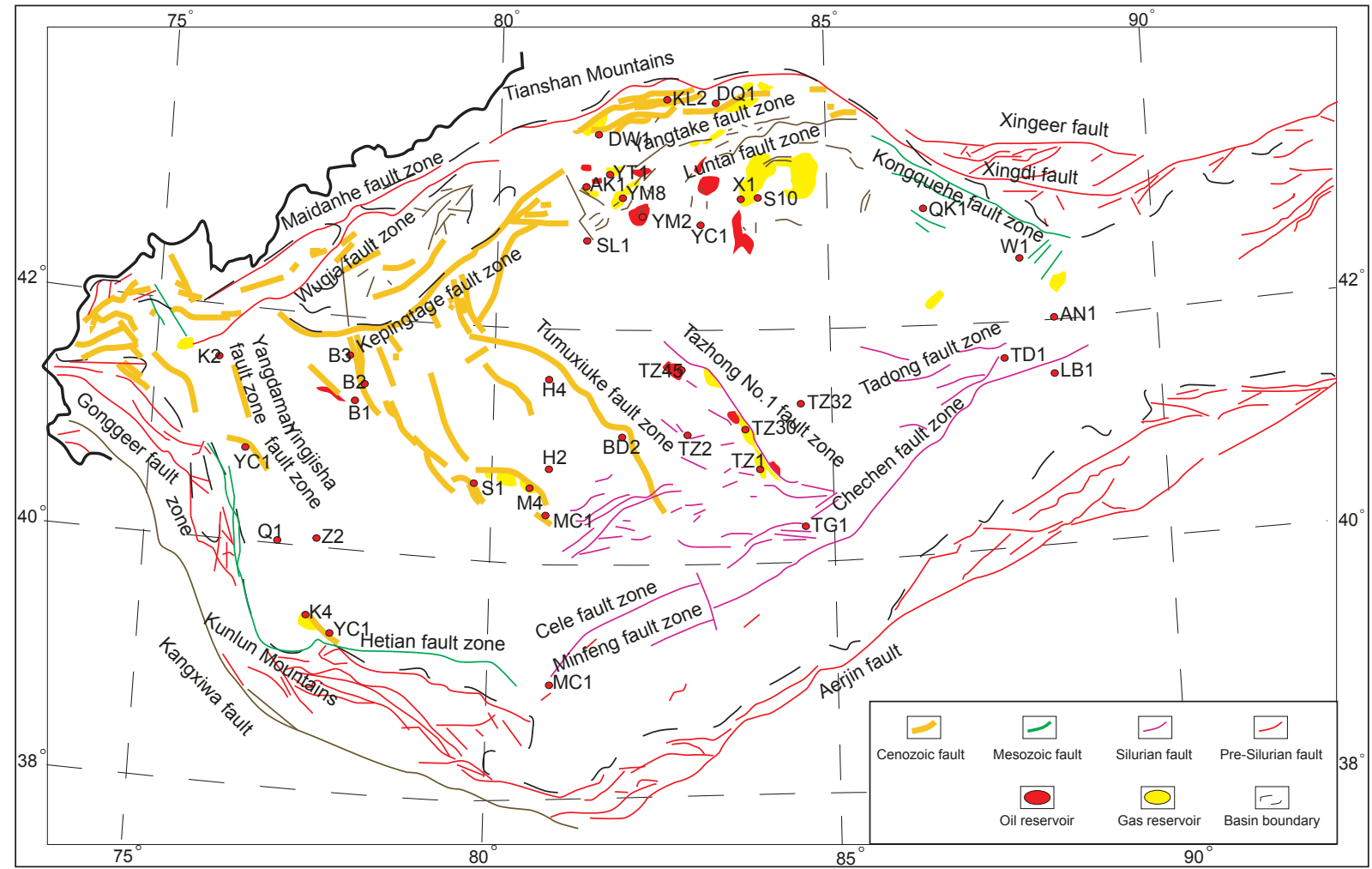

Fig. 9 Control of faults on hydrocarbon distribution and accumulation

reservoirs, and the inversion method of fluid inclusion dating and the forward method of the source rock expulsion characteristics in different geological periods are generally used, rather than the inappropriate K-Ar isotope dating.
According to the results of the two methods, we can see that there are four stages of hydrocarbon accumulation in the Ordovician carbonates of the Tarim Basin: Caledonian, early Hercynian, late Hercynian, and Himalayan. Late Hercynian 
and Himalayan are the vital stages for hydrocarbon distribution and exploration. Fig. 10 shows the results of multi-stage hydrocarbon accumulation. In some areas, just one hydrocarbon accumulation event occurred, and in some areas even no hydrocarbon accumulation event occurred.
This is the results of the forward method, which are generally fewer than those of the fluid inclusion inversion method, because the fluid inclusions record the hydrocarbon adjustment, reconstruction and re-accumulation events after the destruction of early reservoirs.

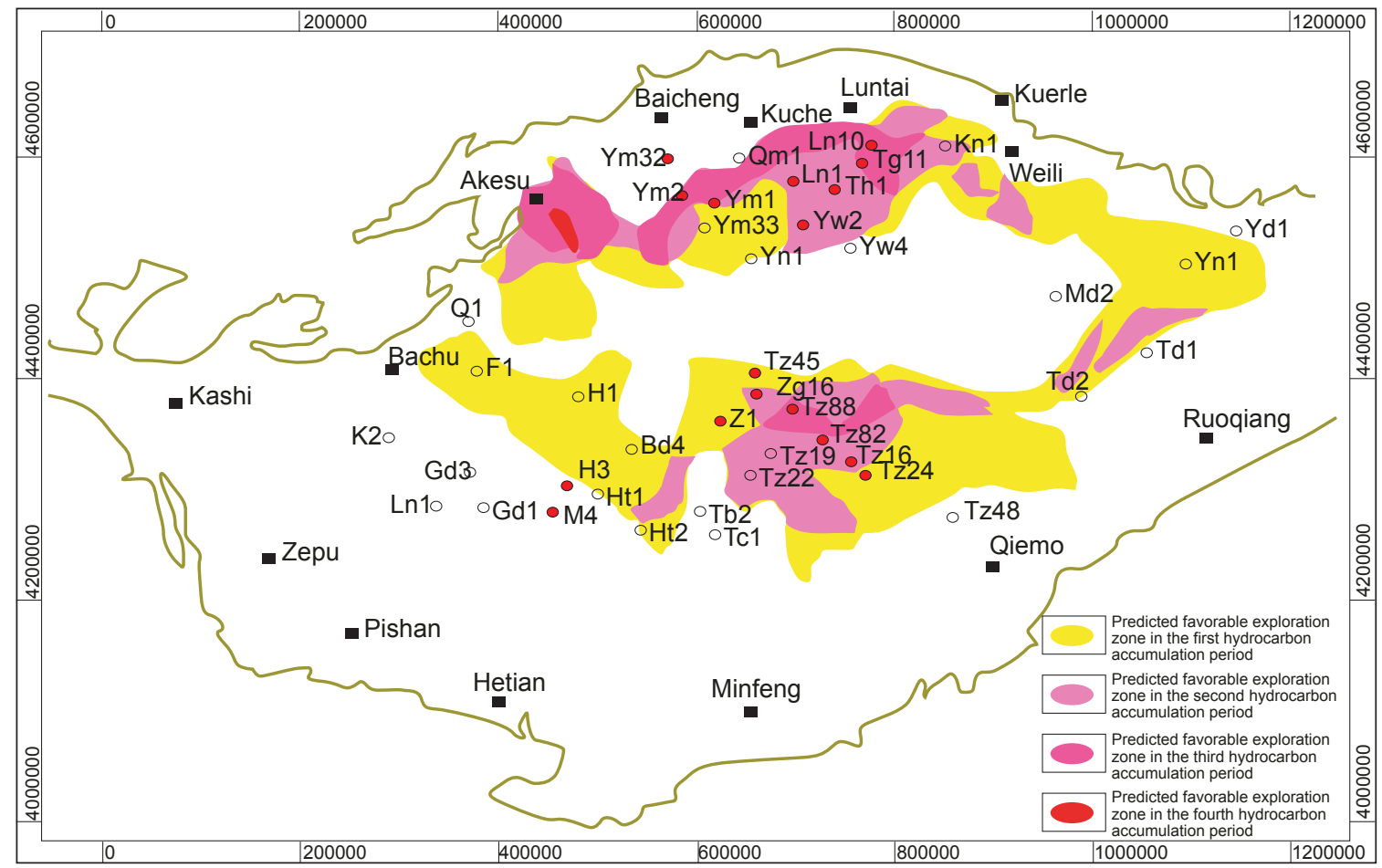

Fig. 10 Predicted favorable exploration areas in different hydrocarbon accumulation periods of the Ordovician by the forward method

5 Major advances and problems in the Ordovician hydrocarbon accumulation model

The hydrocarbon accumulation model of Ordovician in the Tarim Basin has been studied and debated for many years (Table 1). The main problems are about the oil and gas sources, migration pathways, amounts, accumulation periods and dynamics. However, the problems have been partly resolved and a hydrocarbon accumulation model has been presented in recent years. There are four stages of hydrocarbon accumulation and evolution in the Tazhong area, four in the Lunnan, Lunxi and Tahe areas, three in the BachuMaigaiti slope, and two in the Yaha-Yingmaili area (Table 2). To sum up, there are four stages of hydrocarbon accumulation (Fig. 11): Caledonian - the period of reservoir-forming, early Hercynian - the period of reservoir destruction, late Hercynian - the period of reservoir transformation and reaccumulation, and Himalayan - the period of reservoir adjustment and re-accumulation.

\section{Major advances and problems in the main controlling factors and basic rules of hydrocarbon accumulation of Ordovician}

There is still inconsistent knowledge about the main controlling factors and basic rules of hydrocarbon accumulation in superimposed basins. Many scholars tried largely unsuccessfully to elaborate the rules of oil and gas distribution in the Tarim Basin using previous geological theory. The largest difficulty in studying the rules of oil and gas distribution in the Tarim Basin using petroleum system theory is how to recognize the different characteristics of source rocks in different areas and different periods. If the source rock formation history is not considered, the entire Tarim Basin can be considered as a petroleum system because the Cambrian source rocks cover the whole basin. On the other hand, if the source rock formation history is considered, the favorable exploration areas can not be predicted by the distribution of source rocks because many paleo-geological elements during the formation periods of source rocks do not exist at present. It is also difficult to study the rules of oil and gas distribution by petroleum accumulation system, because of multi-period migration and evolution of paleo-uplifts. Moreover, there are big differences of oil and gas distribution characteristics between upper and lower structural layers, so they can not summarized by only one petroleum accumulation system. However, if we divide the upper and lower structural layers into two petroleum accumulation systems respectively, their connection by faults will be neglected because of the independence of petroleum accumulation systems. Therefore, we propose a new hydrocarbon accumulation model by element matching. 
Table 2 Advancements in hydrocarbon accumulation models of Ordovician in the Tarim Basin

\begin{tabular}{|c|c|c|c|c|}
\hline $\begin{array}{l}\text { Research } \\
\text { region }\end{array}$ & $\begin{array}{l}\text { Accumulation and } \\
\text { evolution model }\end{array}$ & Main opinions & Typical case & References \\
\hline Tazhong & Four stages & $\begin{array}{l}\text { Middle-Late Caledonian—hydrocarbon accumulation, Late Hercynian- } \\
\text { reservoir adjustment and hydrocarbon charging, Himalayan — gas invading }\end{array}$ & $\begin{array}{l}\text { Tazhong-82 } \\
\text { well block }\end{array}$ & Han et al, 2009 \\
\hline Lunnan & Four stages & $\begin{array}{l}\text { Late Caledonian-Early Hercynian-accumulation-destruction, Late } \\
\text { Hercynian-reservoir formation and local transformation, Indosinian-Early } \\
\text { Himalayan - development, Late Himalayan-final formation }\end{array}$ & $\begin{array}{l}\text { Lungu11-13 } \\
\text { well block }\end{array}$ & Liu et al, 2004 \\
\hline Tahe & Four stages & $\begin{array}{l}\text { Early Hercynian—hydrocarbon destruction, Late Hercynian—a great } \\
\text { deal of hydrocarbon generation and local destruction, Early Himalayan- } \\
\text { development, Late Himalayan — final formation }\end{array}$ & $\begin{array}{l}\text { Sha- } 48 \\
\text { well block }\end{array}$ & Zhang, 2001 \\
\hline Lunxi & Four stages & $\begin{array}{l}\text { Late Caledonian-Early Hercynian—accumulation-destruction, Late } \\
\text { Hercynian—-hydrocarbon accumulation and degradation, Indosinian- } \\
\text { Yanshan—adjustment, Himalayan—-local gas invading }\end{array}$ & $\begin{array}{l}\text { Lungu-15 } \\
\text { well block }\end{array}$ & Pan et al, 2008 \\
\hline $\begin{array}{l}\text { Bachu-Maigaiti } \\
\text { slope }\end{array}$ & Three stages & $\begin{array}{l}\text { Late Caledonian-Early Hercynian-hydrocarbon local accumulation, Late } \\
\text { Hercynian-local accumulation and local reconstruction, Himalayan-a } \\
\text { great deal of gas invading }\end{array}$ & $\begin{array}{l}\text { Ma-4 well } \\
\text { block }\end{array}$ & Yin et al, 2006 \\
\hline Yaha-Yingmaili & Two stages & $\begin{array}{c}\text { Late Hercynian-local accumulation and local reconstruction, Yanshan- } \\
\text { Himalayan - late hydrocarbon accumulation }\end{array}$ & $\begin{array}{l}\text { Yingmai-1 } \\
\text { well block }\end{array}$ & Shen et al, 2007 \\
\hline
\end{tabular}
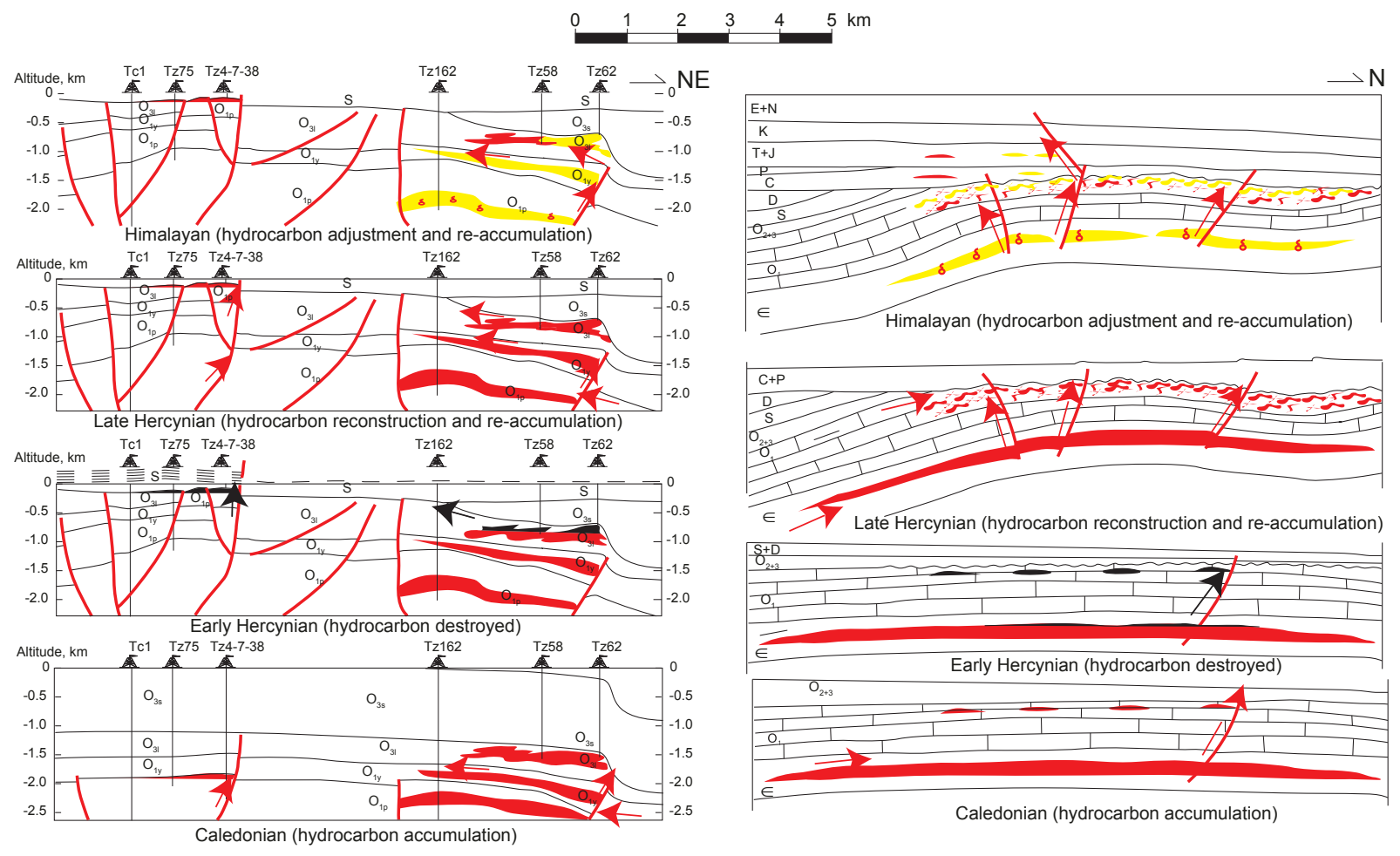

Hydrocarbon accumulation model in Ordovician carbonate reservoirs, Tazhong area

Hydrocarbon accumulation model in Ordovician carbonate reservoirs, Lunnan area

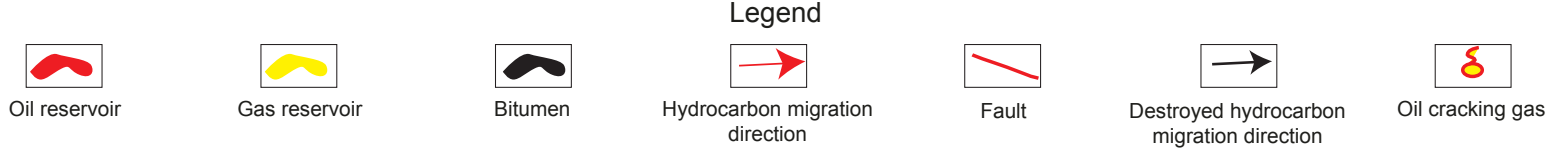

Fig. 11 Hydrocarbon accumulation and evolution model of Ordovician in the Tarim Basin

\subsection{Reservoir formation and distribution in the same period are controlled by four factors}

The formation and distribution of Ordovician carbonate reservoirs in the Tarim Basin are mainly controlled by four factors (Table 3 ), source rocks $(\mathrm{S})$, combination of reservoirseal (C), paleo-uplift (M), and structure balance belt (B).

1) Source rocks $(\mathrm{S})$ controlled the planar range of reservoir distribution. The scale and expulsion quantity of 
source rocks determined the size, distribution area, resource potential and hydrocarbon-bearing property of nearby reservoirs. The research results show that all of 73 middlelarge oil and gas fields were discovered within $100 \mathrm{~km}$ of their source rocks. Generally, the oil and gas expelled from source rocks accumulated in the nearest trap. The closer the oilfield is to the source, the more oil it contains, and the more reservoirs will be discovered. Currently, the discovered oilfields of Ordovician are mainly distributed within $100 \mathrm{~km}$ of the Manjiaer and Awati depressions.

2) Paleo-uplifts (M) dominate oil and gas migration directions. The paleo-uplifts in the basin are the favorable region for hydrocarbon accumulation. The formation and distribution of reservoirs all over the world are all related to paleo-uplifts, except for deep basin gas. Different types of reservoirs were formed in different parts of the paleo-uplift. At present, all the discovered Ordovician reservoirs in the Tarim Basin are all located in the Tazhong, Tabei, and Bachu paleo-uplifts. Weathering crust reservoirs developed on the top of the paleo-uplift; reef and shoal reservoirs developed at the lateral margin of the paleo-uplift; karst-lithology reservoirs developed on the slope; dolomite inner reservoirs developed inside the paleo-uplift (Jiang et al, 2010).

3) A combination of reservoir-seal (C) controlled the reservoir distribution in the section. The physical properties of the formation determined whether reservoirs can be formed and the scale of reservoirs, because oil and gas mainly accumulated in high quality reservoir beds. Four sets of reservoir-seal combinations developed in the Ordovician formations, with an effective porosity of $1.8 \%$, in which all the reservoirs were found.

4) Structure balance belt (B) controlled the residual potential of the reservoirs after adjustment and reconstruction.
It is the region where tectonic movement intensity is relatively small in petroliferous basins. In the earlier formed reservoirs, preservation is especially important. Compared with the uplift exposed to surface, the structure balance belt on the slope showed its superiority, where oil and gas can be preserved. In the late hydrocarbon accumulation, the tectonic hinge zone was the pathway of oil and gas migration, making the structure balance belt be the most favorable region for capturing and preserving oil and gas, and further controlled the residual potential. The exploration cases of the Ordovician in the northern slope of Tazhong, the east slope of Lungu and the south slope of Bachu supported the above opinion.

5) The interaction of the above elements in the same time (T) controls a lot of hydrocarbon accumulation. This is called the accumulation period. In the accumulation period, oil and gas were expelled, migrated, and gathered, until the formed oil and gas reservoirs were reconstructed or destroyed, under the effects of geological action. It corresponded to the whole process of basin sinking, generating and expelling hydrocarbon, uplifting and erosion, involving all the controlling elements at the same time. There are four expulsion peak periods during the evolution of source rocks in the Tarim Basin, so the hydrocarbon accumulation history can be divided into four stages: Late Cambrian-Late Ordovician, Silurian-Late Devonian, Carboniferous-Late Triassic, and Cretaceous-Quaternary.

\subsection{Two modes and five mechanisms restrict the adjustment and reconstruction of reservoirs}

The Ordovician reservoirs in the Tarim Basin generally have the characteristics of early accumulation and late reconstruction and destruction. They can be divided into two modes and five mechanisms (Table 4).

Table 3 Advances in knowledge of the main controlling factors of hydrocarbon accumulation

\begin{tabular}{|c|c|c|c|c|}
\hline $\begin{array}{c}\text { Main controlling } \\
\text { factors }\end{array}$ & $\begin{array}{c}\text { Controlling } \\
\text { characteristics }\end{array}$ & Basic geological model & Controlling mechanisms & References \\
\hline $\begin{array}{l}\text { Source rock } \\
\text { (S) }\end{array}$ & $\begin{array}{c}\text { It controlled horizontal } \\
\text { boundary of reservoir } \\
\text { distribution }\end{array}$ & The relationship between gi & $\begin{array}{l}\text { The scale of the source rocks and their hydrocarbon } \\
\text { generation and expulsion quantity determined the nearby } \\
\text { reservoir size, the distribution area, the resource potential } \\
\text { and the hydrocarbon bearing characteristics. Mid-large oil } \\
\text { and gas fields are all in their surrounding area within } \\
100 \mathrm{~km} \text {. }\end{array}$ & $\begin{array}{l}\text { Dai et al, 1999; } \\
\text { Zhou, } 1997\end{array}$ \\
\hline $\begin{array}{l}\text { Paleo-uplift } \\
\text { (M) }\end{array}$ & $\begin{array}{c}\text { It controlled oil and } \\
\text { gas migration direction }\end{array}$ & 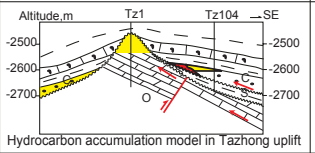 & $\begin{array}{l}\text { The paleo-uplift is the favorable region for hydrocarbon } \\
\text { accumulation. There are different reservoir types in } \\
\text { different parts of the paleo-uplift. Weathering crust } \\
\text { reservoirs mainly formed on the top of paleo-uplift, } \\
\text { reef-bank reservoirs are located at lateral margin, } \\
\text { karst-lithology reservoirs developed on the slope. }\end{array}$ & Jiang et al, 2010 \\
\hline $\begin{array}{l}\text { Combination } \\
\text { of reservoir } \\
\text { and cap } \\
\text { (C) }\end{array}$ & $\begin{array}{c}\text { It controlled oil and } \\
\text { gas vertical distribution }\end{array}$ & Columnar section in Ordovician, Tarim Basin (Fig. 3(a)) & $\begin{array}{l}\text { The formation and distribution of regional cap determined } \\
\text { the formation and distribution of large oilfields. The } \\
\text { physical properties of reservoir bed determined the } \\
\text { hydrocarbon potential of trap and the scale of reservoir. Oil } \\
\text { and gas are mainly accumulated in the combination of } \\
\text { reservoir and caprocks. }\end{array}$ & $\begin{array}{c}\text { Zhang and Zhang, 1989; } \\
\text { Zhou, 2000 } \\
\text { Fu and Fu, } 2001\end{array}$ \\
\hline $\begin{array}{l}\text { Structure } \\
\text { balance belt } \\
\text { (B) }\end{array}$ & $\begin{array}{c}\text { It controlled reservoir } \\
\text { residual potential which } \\
\text { had been adjusted and } \\
\text { reconstructed }\end{array}$ & Hydrocarbon accumulation modolel in Tazhong uplift & $\begin{array}{l}\text { Preservation condition is especially important to early } \\
\text { reservoir forming. Hydrocarbon is preserved well on the } \\
\text { slope in the pivot positions of structural activities which } \\
\text { show its superiority. Structure balance belt is the area } \\
\text { most likely to accumulate oil and gas, because it is on the } \\
\text { way of hydrocarbon migration in the process of later } \\
\text { reservoir forming. }\end{array}$ & Zhou et al, 2004 \\
\hline $\begin{array}{l}\text { Time of } \\
\text { hydrocarbon } \\
\text { accumulation } \\
\text { (T) }\end{array}$ & $\begin{array}{c}\text { It controlled the time } \\
\text { of large amounts of oil } \\
\text { and gas accumulation }\end{array}$ & paleo- ${ }_{\text {time }(\mathrm{T})}$ & $\begin{array}{l}\text { Preservation condition is especially important to early } \\
\text { reservoir forming. Hydrocarbon is preserved well on the } \\
\text { slope in the pivot positions of structural activities which } \\
\text { show its superiority. Structure balance belt is the area } \\
\text { most likely to accumulate oil and gas, because it is on the } \\
\text { way of hydrocarbon migration in the process of later } \\
\text { reservoir forming. }\end{array}$ & $\begin{array}{l}\text { Lü et al, 1996; } \\
\text { Pang et al, } 2006\end{array}$ \\
\hline
\end{tabular}


1) Physical adjustment made early formed reservoirs move after later tectonic events. It is shown by the displacement of reservoir location in plane and the adjustment of oil-gas-water interface in the vertical profile. The Hadson and Tazhong4 oilfields are good cases of this mode.

2) The chemical variations of components, affected by late tectonic events and hydrocarbon charging, changed the oil and gas properties. They can be divided into four types according to their mechanisms: biodegradation, multisource mixing, high temperature cracking and late-stage gas invasion. The main characteristic of these changes is the complexity of oil and gas properties, i.e., the alternate appearance of high production wells, stripped wells and dry wells, and various levels of oil and gas. The Lunnan oilfield, and Tazhong1, Tazhong162, and Lungudong gas fields are examples of this mode.

\subsection{Late hydrocarbon accumulation effects restrict the distribution of oil and gas}

Late hydrocarbon accumulation formed many reservoirs in the latest tectonic movement period (Gong and Wang, 2001). The Ordovician reservoirs in the Tarim Basin have four accumulation stages, and the early formed reservoirs are reconstructed in the late period. The former reservoirs are destroyed, and the secondary reservoirs are formed in late period (Zhao and Li, 2002). These reservoirs coexist with the reservoirs formed in late period. In short, the former oil and

Table 4 Advances in understanding reservoir reconstruction and destruction mechanisms

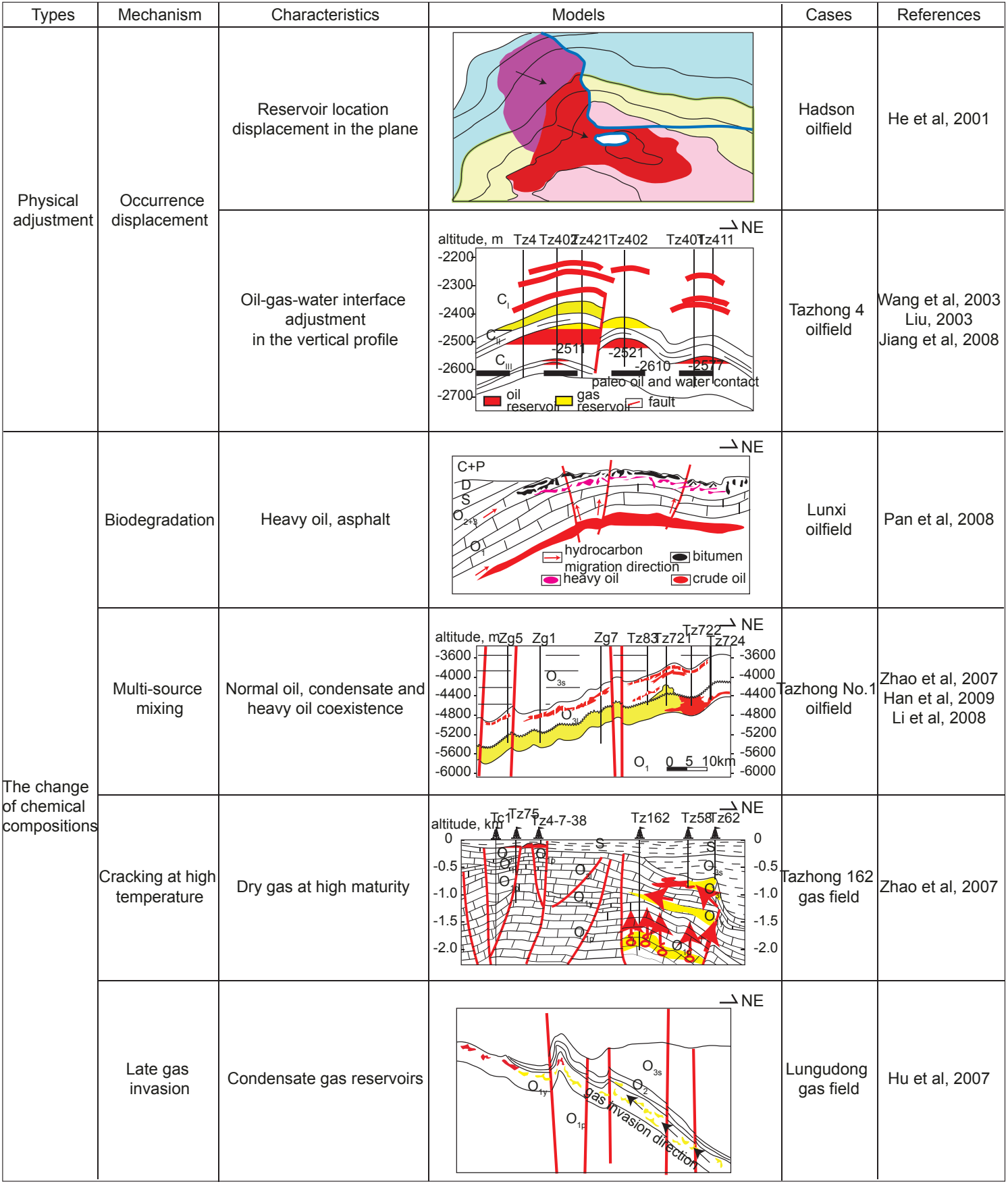


gas reservoirs will be destroyed, adjusted and reconstructed by later multiple tectonic activities and new reservoirs are formed or the new secondary reservoirs coexist with the former destroyed or adjusted reservoirs, generally showing the late hydrocarbon accumulation characteristics.

The multiple tectonic events are the essential reason of late hydrocarbon accumulation effects in superimposed basins (Fig. 12). The tectonic event model in superimposed basins can be divided into five types as follows:

1) Early-middle-late continuous deposition. Reservoirs formed in the early stage and became cracking gas pools in the late stage (favorable for reservoir forming, such as the
Tazhong1 gas field).

2) Early deposition and late tectonic deformation. Lots of formed reservoirs were destroyed (not favorable for reservoir formation, like the Tazhong75 oilfield) and a few secondary oil and gas reservoirs formed.

3) Early and late deposition and middle-stage tectonic deformation. Reservoirs formed early were destroyed in the middle stage and reformed in the late stage (relatively favorable for reservoir forming, such as the Tazhong 1 oilfield). Then they coexist with the new reservoirs in late stage.

4) Early tectonic deformation and late deposition.
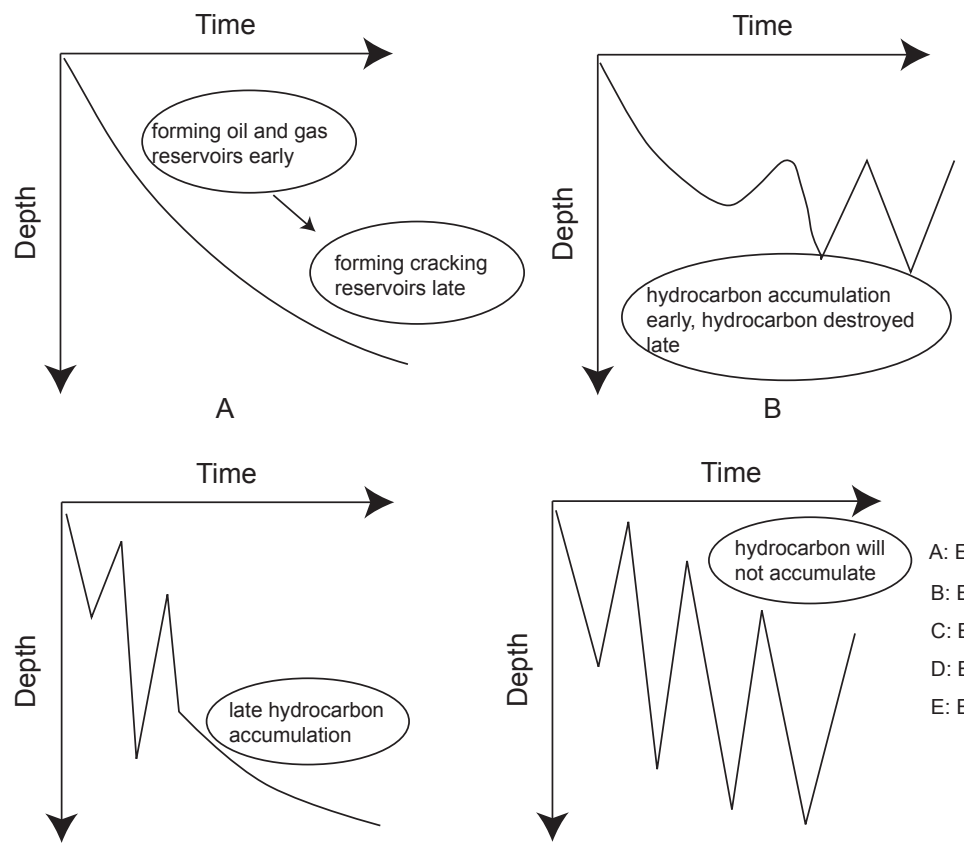

D
Fig. 12 Late-stage hydrocarbon accumulation effects

E

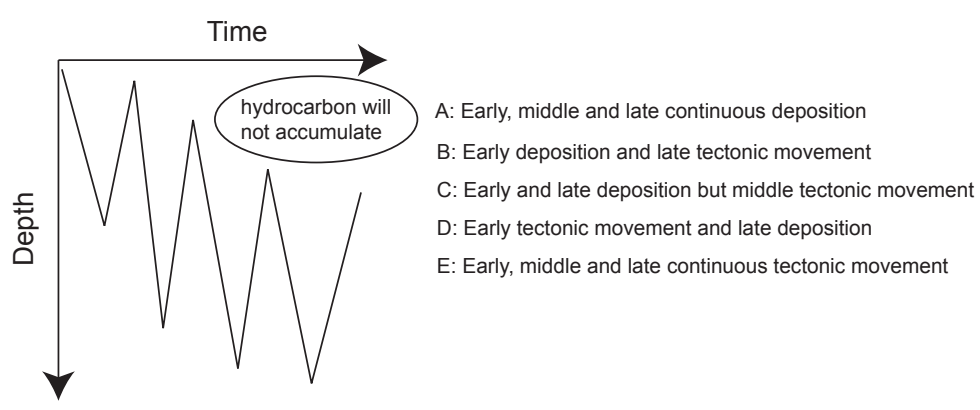

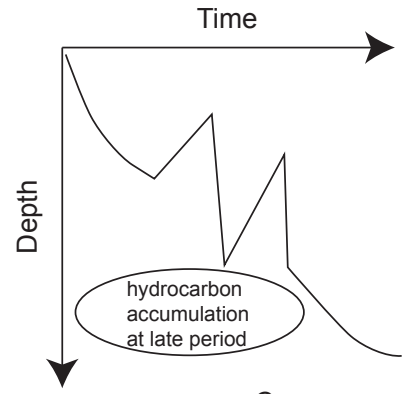

C
Reservoirs are not easy to form in the early stage, but are easy to form in the late stage (relatively favorable for reservoir forming, such as the Yaha-Yingmaili region).

5) Early-middle-late continuous tectonic deformation. Reservoirs can not be formed easily, even some reservoirs are preserved, and only the secondary reservoirs could be formed at the late stage.

\subsection{Reservoir distribution rule}

The hydrocarbon distribution model of element matching, process superimposition, and facies and potential location is proposed based on understanding the main controlling factors of Ordovician carbonate reservoirs in the Tarim Basin, as shown in Table 5.

1) The element matching hydrocarbon accumulation model refers to four elements: structure balance belt (B), combination of reservoir-seal (C), paleo-uplifts (M) and source rocks $(\mathrm{S})$. Their effective matching determined the formation and distribution of reservoirs. The effective matching includes three implications: four elements combined in order (BCMS from top to bottom) in vertical section determined the target interval; four elements superimposed in plane determined the hydrocarbon accumulation area; four elements in the same geological period $\left(\mathrm{T}_{\mathrm{B}}=\mathrm{T}_{\mathrm{C}}=\mathrm{T}_{\mathrm{M}}=\mathrm{T}_{\mathrm{S}}\right)$ restricted the hydrocarbon accumulation time. This model can be simply called T-BCMS. For the same target interval, it may have single-period hydrocarbon accumulation, or has multi-period hydrocarbon accumulation. For the basin having multi-period hydrocarbon accumulation, determining the most favorable exploration areas in different hydrocarbon accumulation periods is as follows. First, determining the four elements in different periods $\left(\mathrm{T}_{1}, \mathrm{~T}_{2}, \ldots \mathrm{T}_{n}\right)$ in the same target interval, respectively. Then determining the favorable area $A_{1}$ in the first hydrocarbon accumulation period, the favorable area $A_{2}$ in the second hydrocarbon accumulation period, the favorable area $\mathrm{A}_{n}$ in the $n$th hydrocarbon accumulation 
period. Finally, the superimposition of $\mathrm{A}_{1}, \mathrm{~A}_{2}, \ldots \mathrm{A}_{n}$ is the most favorable area for hydrocarbon accumulation.

2) Process superimposition model. The earlier reservoirs were affected by the late tectonic activities. The reservoirs may be destroyed completely if the tectonic activity was strong. However, if the tectonic activity was weak, the reservoirs may be preserved. For making clear the relationship between tectonic intensity and reservoirs, the relationship between oil and gas productivity and the denuded thickness of overlying formation of Ordovician reservoirs was analyzed. The results showed that if the denuded thickness of overlying formation was over than $200 \mathrm{~m}$, meaning strong tectonic activity, the former reservoirs in the platform of the Tarim Basin would be completely destroyed, and the oil and gas productivity was under $1 \mathrm{t}$ per day. If the denuded thickness is less than $50 \mathrm{~m}$, meaning weak tectonic activity, the oil and gas would be well preserved. The adjustment, reconstruction, destruction of former reservoirs under multi-period tectonic activities in the same area can be summarized into the following three aspects. The destroyed reservoirs are in the superimposed area of strong tectonic activities, the adjusted reservoirs are in the superimposed area of weak tectonic activities, and the reconstructed reservoirs are in the other superimposed area. In short, the reservoirs will be destroyed in strong-strong superimposed area, and the reservoirs will be preserved in weak-weak superimposed area. The amount of destroyed hydrocarbon by tectonic activities can be calculated on the basis of this theory, and the most favorable exploration zone from the favorable accumulation area can be chosen (Pang et al, 2010).

3) Facies and potential location model. The superimposed basins are characterized by multiple periods of hydrocarbon accumulation and effective late hydrocarbon accumulation. In spite of multi-period hydrocarbon accumulation which occurred in superimposed basins, the late hydrocarbon accumulation is the most significant (Kang et al, 2010). Because the late tectonic activity created the final condition for hydrocarbon adjustment, and the final target of hydrocarbon adjustment and reconstruction was adapting the late structural pattern. The structural high may be the most favorable exploration targets. The reservoirs formed in the late period determined the reservoir distribution in the basin, because they would never be affected by late tectonic events. Most of the reservoirs which have been found are formed in the late period in superimposed basins. The adjusted reservoirs coexisting with the late reservoirs reflected that the present structural high, sedimentary facies and fluid potential controlled the distribution of oil and gas. Under the late structural pattern, the favorable facies and low potential area is the most favorable for hydrocarbon accumulation. The favorable facies means the bioherm and grainstone bank in carbonate rocks, and siltstone and fine sandstone of foreshore-shoreface facies in clastic rocks. The low potential area means the structural high with low position energy, the fault zone with low pressure energy, the high porosity and permeability reservoirs with low interfacial energy, including limestone in reef, cave carbonate, and fractured dolomite. The most favorable exploration targets could be predicted by the facies and potential location model.

\section{Main problems in Ordovician hydrocarbon accumulation mechanisms}

\subsection{Dynamic mechanisms of oil and gas accumulation}

The hydrocarbon migrated and accumulated by buoyancy in clastic rocks, the discharge and migration of formation water by compaction played an important role in hydrocarbon accumulation. However, compaction was very limited in carbonate formations, and the buoyancy had little effect on hydrocarbon accumulation because the formation water stagnated. Therefore, it is difficult to explain the dynamic mechanisms of hydrocarbon migration and accumulation, and it needs further study. The dynamic mechanisms of hydrocarbon accumulation are the fluid mechanisms of the processes of reservoir formation, evolution, reconstruction and destruction (Hao et al, 2000). Reservoirs with different dynamic genesis have different distribution rules, controlling factors and occurrence features (Pang et al, 2000). The research into dynamic mechanisms and genetic models of migration and accumulation is of great significance in guiding oil and gas exploration and increasing benefits.

\subsection{Variation characteristics of reservoir oil-bearing property and quantitative models}

The research on oil-bearing potential in traps becomes more and more important with the development of exploration practice, and the oil-bearing properties are very complex in the Tarim Ordovician carbonate reservoirs. Considering the variations of hydrocarbon-filling degree, oil saturation and well productivity in one trap (e.g. the traps on the Tazhong-1 break slope), how should we forecast this kind of trap? Pang et al (2007) built the sedimentary facies-fluid potential-source matched model of controlling reservoirs through analyzing many controlling factors of oil-bearing property. This model can be used to forecast oil-bearing potential in clastic traps and achieved success in eastern basins. The research into using this method in carbonate traps of superimposed basins should be strengthened.

\section{Conclusions}

1) The Ordovician crude oil in the Tarim Basin mainly originated from Cambrian-Ordovician mixed sources. The mixed amount of crude oil from Cambrian-Lower Ordovician in Tazhong is distributed in the wide range of 13\%-91\%, and some are residual oil reservoirs with the mixed amount up to $100 \%$. Natural gas generally came from Cambrian-Lower Ordovician, mainly oil cracked gas.

2) Hydrocarbon mainly migrated through unconformities and faults. The hydrocarbon migrated from northeast to southwest and from northwest to southeast in the Tazhong area, from southwest to northeast and from southeast to northwest in the Lunnan area, and from south to north and 
Table 5 Complex reservoir distribution rules in superimposed basins (the T-BCMS model)

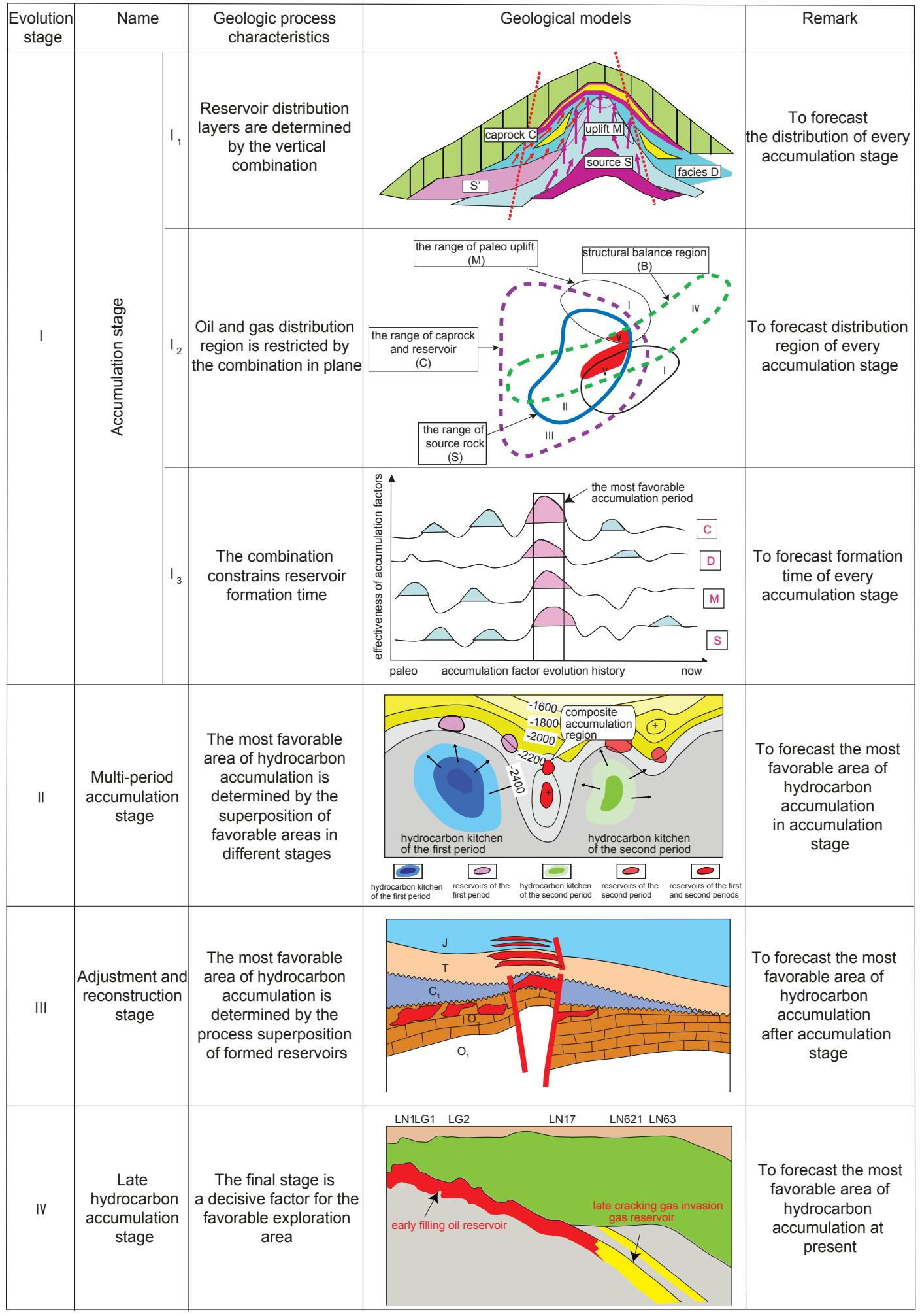

from north to south in the Yaha-Yingmaili area.

3) There are four stages of hydrocarbon accumulation: Caledonian, early Hercynian, late Hercynian and Himalayan. The hydrocarbon reservoirs formed in the late Hercynian and Himalayan periods are of the greatest significance in exploration.
4) The formation and evolution of hydrocarbon reservoirs can be divided into four stages: Caledonian-hydrocarbon forming stage, early Hercynian-destruction stage, late Hercynian - hydrocarbon reconstruction and re-accumulation stage, and Himalayan - hydrocarbon adjustment and reaccumulation stage. 
5) Element matching, process superimposition, and facies and potential location in late stage control the accumulation and distribution of hydrocarbon reservoirs. Hydrocarbon source rock (S), reservoir-seal combination (C), paleo-uplift (M) and structure balance belt (B) matching in the same time $(\mathrm{T})$ control the favorable exploration areas. Process superimposition of multi-stage tectonic activities control the adjustment, reconstruction and destruction of reservoirs. The reservoirs will be destroyed in strong-strong tectonic activity superimposed areas, and the reservoirs will be preserved in weak-weak tectonic activity superimposed areas, which are the most favorable zone for exploration. Late tectonic activities are the most significant in hydrocarbon accumulation. They control the reservoir formation and distribution. The favorable facies and low potential zone form the most favorable exploration target.

\section{Acknowledgements}

This work is supported by the National Basic Research Program of China (973 Program, Grant No.2006CB202308).

\section{References}

Cai C F, Wu G H, Li K K, et al. Thermochemical sulfate reduction and origin of sulfur in crude oils in Palaeozoic carbonates. Bulletin of Mineralogy, Petrology and Geochemistry. 2007. 26(1): 44-48 (in Chinese)

Dai J X, Xia X Y, Hong F, et al. The main controlling factors of the formation of large-medium coal-formed gas fields. Chinese Science Bulletin. 1999. 44(22): 2455-2464 (in Chinese)

$\mathrm{Fu} \mathrm{G}$ and Fu X F. Controlling of fault transport system and its combination to the formation and distribution of oil or gas reservoirs. Global Geology. 2001. 20(4): 345-350 (in Chinese)

Gong Z S and Wang G C. Neotectonism and late hydrocarbon accumulation in the Bohai Sea. Acta Petrolei Sinica. 2001. 22(2): 1-7 (in Chinese)

Guo J J, Chen J F, Wang T G, et al. Oil migration orientation of the Ordovician in the Tazhong uplift. Journal of Southwest Petroleum University (Science \& Technology Edition). 2008. 39(3): 8-13 (in Chinese)

Han J F, Mei L F, Yang H J, et al. Non-hydrocarbon origin of Ordovician natural gas in Tazhong of Tarim Basin and its implications for nonhydrocarbon accumulation. Earth Science Frontiers. 2009. 16(1): 314-325 (in Chinese)

Hao F, Zou H Y and Jiang J Q. Dynamics of petroleum accumulation and its advances. Earth Science Frontiers. 2000. 7(3): 11-21 (in Chinese)

He W Y, Zheng D M, Li J H, et al. Oil and gas accumulation mechanism in Hadexun zone of the Tarim Basin. Geology Geochemistry. 2001. 29(3): 15-17 (in Chinese)

Hu J F, Cai Z Z, Ma Q, et al. Characteristics and main controlling factors of the Ordovician carbonate rock reservoirs in Lungudong area, Tarim Basin. Oil \& Gas Geology. 2007. 28(6): 776-783 (in Chinese)

Jiang Z X, Li Z, Pang X Q, et al. Analysis of differences of hydrocarbon enrichment in the upper and lower structural layers in the Tazhong palaeo-uplift. Chinese Journal of Geology. 2010. in press

Jiang Z X, Yang J, Pang X Q, et al. Property differences and genetic mechanisms of hydrocarbon in each oil unit of the Carboniferous in Tazhong-4 oilfield. Oil \& Gas Geology. 2008. 29(2): 159-166 (in Chinese)

Kang D J, Pang X Q and Kuang J. Tectonic disturbances in west China's typical superimposed basins and late hydrocarbon reservoir formation. Chinese Journal of Geology. 2010. in press
Kang Y Z. The geological conditions for occurrence of giant fields of Ordovician in the Tarim Basin. Xinjiang Geology. 1999. 17(2): 97109 (in Chinese)

Li Q M, Wu G H, Pang X Q, et al. Hydrocarbon accumulation conditions and exploration direction of Cambrian-Ordovician carbonates of the Tarim Basin. Chinese Journal of Geology. 2010a. in press

Li S M, Pang X Q, Yang H J, et al. Characteristics and genetic type of the oils in the Tazhong Uplift. Earth Science-Journal of China University of Geosciences. 2008. 33(5): 635-642 (in Chinese)

Li S M, Pang X Q, Yang H J, et al. Origin of crude oils in the Lunnan region, Tarim Basin. Chinese Journal of Geology. 2010b. in press

Liang D G, Zhang S C, Zhang B M, et al. Understanding of marine oil generation in China based on the Tarim Basin. Earth Science Frontiers. 2000. 7(4): 534-547 (in Chinese)

Liu J J, Liu H R, Tan L, et al. Reservoir characteristics and distributions of the Ordovician buried hill reservoir in Lunnan, Tarim Basin. Chinese Journal of Geology. 2004. 39(4): 532-542 (in Chinese)

Liu K Q. Petroleum accumulation analysis of TZ4 oilfield in the Tarim Basin. Journal of Xinjiang Petroleum Institute. 2003. 15(4): 1-4 (in Chinese)

Lü X X, Jin Z J, Zhou X Y, et al. Characteristics of Ordovician carbonate hydrocarbon enrichment in the Lunnan area of the Tarim Basin. Chinese Science Bulletin. 2004. 49(Supplement): 54-58 (in Chinese)

Lü X X, Yang H J, Yang N, et al. Further recognition of petroleum exploration potential of marine carbonates in the western Tarim Basin. Petroleum Science. 2007. 4(3): 21-25

Lü X X, Zhang Y W and Jin Z J. An initial discussion of reservoir formation cycles in the Tarim Basin. Chinese Science Bulletin. 1996. 41(22): 2065-2067 (in Chinese)

Pan W Q, Zhao M J, Zhang B M, et al. Ordovician buried hill oilfield in western Lunnan area: An example of heavy oilfield formation for hydrocarbon charging and degrading in Hercynian period. Chinese Journal of Geology. 2008. 43(2): 321-332 (in Chinese)

Pang X Q, Gao J B and Meng Q Y. A discussion of the relationship between tectonization and hydrocarbon accumulation and dissipation in the platform-basin transitional area of the Tarim Basin. Oil \& Gas Geology. 2006. 27(5): 594-603 (in Chinese)

Pang X Q, Jin Z J and Zuo S J. Dynamics, models and classification of hydrocarbon accumulations. Earth Science Frontiers. 2000. 7(4): 507-514 (in Chinese)

Pang X Q, Li P L, Zhang S W, et al. Control of facies-potential coupling on hydrocarbon accumulation in continental faulted basins and its basic geological models. Oil \& Gas Geology. 2007. 28(5): 641-652 (in Chinese)

Pang X Q, Zhou X Y, Wang H J, et al. Adjustment and alteration of petroleum reservoirs after their formation in the Tarim Basin and the resource quantitative evaluation. Chinese Journal of Geology. 2010. in press

Shao Z B. Research on the characteristics of the neutral nitrogen compounds and oil migration in Ordovician crude oil from the Tahe Oil Field, Tarim Basin. Petroleum Geology \& Experiment. 2005. 27(5): 496-501 (in Chinese)

Shen A J, Wang Z M, Zheng X P, et al. Genesis classification and characteristics of Cambrian-Ordovician carbonate reservoirs and petroleum exploration potential in Yaka-Yengimahalla area, Tarim Basin. Marine Origin Petroleum Geology. 2007. 12(2): 23-32 (in Chinese)

Shou J F, Shen Y, Zhang H L, et al. Characteristics of MesozoicCenozoic tectonic diagenesis in the Kuqa area of the Tarim Basin, China. Petroleum Science. 2009. 6(4): 366-375

Wang F Y, Zhang S C, Zhang B M, et al. Maturity and its history of Cambrian marine source rocks in the Tarim Basin. Geochimica. 2003. 32(5): 461-468 (in Chinese)

Yang H J, Han J F, Chen L X, et al. Characteristics and patterns of 
complex hydrocarbon accumulation in the Lower Paleozoic carbonate rocks of the Tazhong Palaeouplift. Oil \& Gas Geology. 2007a. 28(6): 784-790 (in Chinese)

Yang H J, Wu G H, Han J F, et al. Characteristics of hydrocarbon enrichment along the Ordovician carbonate platform margin in the central uplift of the Tarim Basin. Acta Petrolei Sinica. 2007b. 28(4): 26-30 (in Chinese)

Yin W, Fan T L, Wang H Y, et al. Controlling factors of hydrocarbon migration in Bachu area of Tarim Basin. Northwestern Geology. 2006. 39(3): 75-82 (in Chinese)

Zhang H F and Zhang W X. Petroleum Geology (The Second Edition). Beijing: Petroleum Industry Press. 1989 (in Chinese)

Zhang K. The characteristics of Tahe oilfield and the oil-gas exploration direction in the carbonates of Tarim Basin. Acta Petrolei Sinica. 2001. 22(4): 1-6 (in Chinese)

Zhang S C, Zhang B M, Wang F Y, et al. Middle-upper Ordovician: the main source beds of the Tarim Basin. Marine Origin Petroleum Geology. 2000. 5(2): 16-22 (in Chinese)

Zhao J Z and Li Q M. Timing and history of marine hydrocarbon accumulation in the Tarim craton basin. Chinese Science Bulletin. 2002. 47(Supplement): 116-121 (in Chinese)

Zhao M J, Zhang S C and Liao Z Q. The cracking gas from crude oil and its significance in gas exploration. Petroleum Exploration and Development. 2001. 28(4): 47-56 (in Chinese)

Zhao Z J, Wang Z M, Wu X N, et al. Genetic types and distribution forecast of available carbonate reservoirs in the Ordovician in the central area of the Tarim Basin. Petroleum Geology and Experiment. 2007. 29(1): 40-47 (in Chinese)

Zhou X X. Essentials about hydrocarbon distribution controlled by source and seal. Petroleum Exploration and Development. 1997. 24(6): 4-7 (in Chinese)

Zhou X X. The petroleum reservoir-forming characteristics of the composite superimposed basin-An example from the Tarim Basin. Earth Science Frontiers. 2000. 7(3): 39-47 (in Chinese)

Zhou X Y, Lü X X, Jin Z J, et al. Accumulation of petroleum in the carbonate rocks in the pivot positions of structural activities in the Tarim Basin. Journal of Xi'an Shiyou University (Natural Science Edition). 2004. 19(4): 19-25 (in Chinese)

Zhou Y C, Wang X W and Yang G L. Oil and gas pool forming condition and exploration prospects of Ordovician carbonate rocks in the Akekule region, Tarim Basin. Oil \& Gas Geology. 2000. 21(2): 104109 (in Chinese) 